\title{
Nicotine attenuates the effect of HIV-1 proteins on the neural circuits of working and contextual memories
}

\author{
Tanseli Nesil ${ }^{1}$, Junran Cao' ${ }^{1}$ Zhongli Yang ${ }^{2}$, Sulie L. Chang ${ }^{2,3}$ and Ming D. Li ${ }^{1 *}$
}

\begin{abstract}
Background: Human immunodeficiency virus (HIV)-1-associated neurocognitive disorders (HAND) are characterized by synaptic damage and neuronal loss in the brain. Excessive glutamatergic transmission and loss of cholinergic neurons are the major indicators of HAND. Nicotine acts as a cholinergic channel modulator, and its cognitive-enhancing effect in neurodegenerative and cognitive disorders has been documented. However, it is unclear whether nicotine has any positive effect on memory and synaptic plasticity formation in HAND.
\end{abstract}

Methods: We investigated the effects of nicotine on synaptic plasticity and hippocampus-prefrontal cortex (PFC)-amygdala-dependent memory formation in the HIV-1 transgenic ( $\mathrm{Tg}$ ) and F344 control rats.

Results: Chronic nicotine treatment $(0.4 \mathrm{mg} / \mathrm{kg}$ nicotine, base, subcutaneously) significantly attenuated the cognitive deficits in the HIV-1Tg rats in both the spatial and contextual fear memories but impaired the contextual learning memory in the F344 rats. To determine the role of nicotine in the synaptic dysfunction caused by HIV-1 proteins, we analyzed the expression of key representative genes related to synaptic plasticity in the hippocampus, PFC, and amygdala of the HIV-1Tg and F344 rats using a custom-designed qRT-PCR array. The HIV-1 proteins significantly altered the glutamate receptor-mediated intracellular calcium cascade and its downstream signaling cascade in a brain region-specific manner. Further, chronic nicotine treatment reversed the effect of HIV-1 proteins on the expression of genes involved in synaptic plasticity in the three brain regions. The effects of nicotine differed significantly in the HIV-1Tg and F344 rats.

Conclusions: Our findings indicate that nicotine can attenuate the effect of HIV viral proteins on cognitive function and produce a brain region- and strain-specific effect on the intracellular signaling cascades involved in synaptic plasticity and memory formation.

Keywords: HIV, Nicotine, Brain, Spatial working memory, Contextual memory, Synaptic plasticity

\section{Introduction}

Human immunodeficiency virus (HIV)-1 proteins penetrate the central nervous system (CNS) during the early stages of viral infection and induce progressive neuronal damages in the brain $[1,2]$. HIV-1-associated neurocognitive disorders (HAND) are the major CNS complications of HIV-1 infection, with approximately $50 \%$ of patients developing some degrees of cognitive impairment [3]. Working (short-term) and episodic memory

\footnotetext{
* Correspondence: ml2km@virginia.edu

1 Department of Psychiatry and Neurobehavioral Sciences, University of Virginia, 450 Ray C Hunt Drive, Suite G-170, Charlottesville, VA 22903, USA Full list of author information is available at the end of the article
}

(involving short-term and long-term memory) impairments are the most commonly observed cognitive deficits in the HAND patients [3-5]. Recent studies have revealed that progression of HAND is accelerated by drug abuse in the HIV-1-infected patients. Cigarette smoking has a high prevalence in the HIV population, which abuses multiple drugs $[6,7]$. It has been reasoned that the high prevalence of smoking in HIV-1-infected patients is attributable to the compensatory effect of smoking on cognitive deficits [7].

Nicotine is the main psychoactive component of cigarette smoke, and it has variable effects on cognitive function. There has been relatively little research on the 
relation between nicotine and progression of HAND. Recently, Wojna et al. [8] reported that HIV-1-infected smokers exhibited less cognitive impairment than infected non-smokers. Studies of animal models of HIV-1 infection demonstrate that chronic nicotine treatment restored the effect induced by viral proteins on the multiple intracellular signaling pathways in the different brain regions of the HIV-1Tg rats [9]. However, nicotine-induced molecular alterations in the neural circuits of working and episodic memory have not been fully elucidated in the presence of HIV-1 viral proteins.

Memory formation depends on the activity of interconnected neurons through synapses within the hippocampus, prefrontal cortex (PFC), and amygdala [10]. The dynamic interaction between glutamatergic and cholinergic synapses has a major role in encoding of new information into short-term and long-term memories [11, 12]. Dysfunction in the brain glutamatergic and cholinergic neurotransmission is postulated to be one of the contributors to memory impairment during HIV-1 infection $[13,14]$. The effects of HIV-1 proteins on the glutamatergic neurotransmission system have been investigated $[15,16]$. Results from these studies show that HIV viral proteins induce excessive glutamate release from infected microglia cells and result in glutamate-mediated neurotoxicity in the cortical and subcortical regions of the brain [16]. Further, mechanistic studies of HIV-1 infection have demonstrated that viral proteins lead to glutamate-induced deregulation of calcium homeostasis by overactivating N-Methyl-D-aspartic acid (NMDA) and metabotropic glutamate receptors (mGluRs). Activation of these receptors enhances subsequent calciummediated apoptosis signaling in the neurons $[13,17,18]$. Recent studies also showed that brain cholinergic neurons are affected by HIV viral proteins [13, 14]. Depboylu et al. [19] reported that chronic inflammation acted as a key mediator of HIV-1 protein-induced cholinergic dysfunction and neuronal loss in the brain that contributes to learning and memory impairment.

Stimulation of the cholinergic system by nicotinic acetylcholine receptor (nAChR) agonists protects against glutamate-mediated neurotoxicity and leads to subsequent cognitive improvement in rodent models of neurodegenerative disorders [20]. A low dose of nicotine enhances cognitive performance by attenuating the impairment of cholinergic neurotransmission [21, 22]. Experimental treatment of neurodegenerative disorders shows that nicotine mediates neuroprotection against NMDA-mediated excitotoxicity in the neurons by calcium-dependent mechanisms via neuronal $\alpha 4 \beta 2$ - and $\alpha 7$-containing nAChRs [23-26]. These results indicate that nicotine has a modulatory effect on the neuronal circuitry of learning and memory during glutamatemediated excitotoxicity and neurodegeneration.
The main goal of the current study was to determine how nicotine induces behavioral and molecular alterations in cognitive-impaired HIV-1Tg rats. From these experiments, we aimed to answer the following two interrelated questions: (1) does chronic nicotine treatment attenuate HIV-1-associated cognitive impairment? And (2) does nicotine show differential effects on intracellular signaling mechanisms underlying the synaptic plasticity formation of the HIV-1Tg rats in comparison to the F344 control animals? We addressed the first question by testing HIV-1Tg and F344 rats for spatial working memory in the Y-maze and then for contextual fear memory in the passive avoidance test. We then answered the question further by analyzing the transcription of genes involved in synaptic plasticity in the hippocampus, PFC, and amygdala of the same set of rats.

\section{Materials and methods}

Animals

Male HIV-1Tg and F344 genetic background control rats (Harlan Industries, USA) at 7 to 8 weeks of age were used. Rats were housed two per cage in a temperature $\left(20{ }^{\circ} \mathrm{C}-22{ }^{\circ} \mathrm{C}\right)$ - and humidity $(45 \%-55 \%)$-controlled environment on a 12-h light/dark cycle. Food and water were provided ad libitum. All behavioral experiments were conducted between 9:00 AM and 1:00 PM and were in accordance with the guideline of the University of Virginia Animal Research Committee.

\section{Drugs and treatment}

Rats from each strain were divided randomly into two groups: saline-treated control and nicotine treated, designated as follows: F344_Saline $(\mathrm{n}=11)$; F344_Nicotine $(\mathrm{n}=12)$; HIV-1Tg_Saline $(\mathrm{n}=9)$; HIV-1Tg_Nicotine $(\mathrm{n}=$ 11). To determine the effects of chronic nicotine treatment on spatial working and contextual memory, F344 and HIV-1Tg rats received a single subcutaneous injection of either saline or nicotine at a dose of $0.4 \mathrm{mg} / \mathrm{kg} /$ day (nicotine free base) for 15 days before starting the behavioral experiments.

(-)-Nicotine hydrogen tartrate (Sigma, St. Louis, MO) was dissolved in $0.9 \%$ physiological saline, and its concentration was calculated as nicotine free base. On day 15 , rats were tested for their spatial working memory in the Y-maze with the spontaneous alternation behavioral paradigm. Contextual fear memory experiments were conducted 1 week after the spontaneous alternation behavior test. Between days 22 and 26, rats were tested for short- and long-term contextual fear memory performance in the passive avoidance box with the one-stepthrough passive avoidance protocol. All rats received their last nicotine or saline injection on day 27 and were decapitated within $24 \mathrm{~h}$ after the last injection. Because of congenital cataracts of the HIV-1Tg rats, all behavioral 
experiments were conducted under dimmed red light to minimize the visual differences between the strains.

\section{Y-maze task test}

Spatial working memory performance of HIV-1Tg and F344 rats was assessed by recording spontaneous alternation behavior during an 8-min session in the Y-maze test apparatus according to published protocols [27, 28]. The Y-maze has three arms, each $45 \mathrm{~cm}$ long, $10 \mathrm{~cm}$ wide, and $35 \mathrm{~cm}$ high. The arms were positioned at equal angles and converged in an equilateral triangular central area. Each rat was placed at the end of an arm and allowed to move freely through the Y-maze without reinforcements such as food, water, or electric shock. The series of arm entries was recorded by the Any-Maze video tracking system (Stoelting Co., Wood Dale, IL, USA). An arm entry was said to be complete when all four paws of the subject had been placed in the arm. Alternation behavior (actual alternations) was defined as successive entries into the three arms with overlapping triplet sets. The percent alternation was calculated as the ratio of actual alternation to possible alternations (total number of arm entries -2 ) $\times 100$.

\section{Passive avoidance test}

The multiple trial one-step-through passive avoidance experiments were carried out between Days 22 and 26 with the goals of testing acquisition and short- and long-term contextual memory. The passive avoidance apparatus (Coulbourn Instruments Inc. Whitehall, PA, USA) consists of two compartments (illuminated and darkened) both equipped with a grid floor. The two compartments are separated by an automatic guillotine door.

The one-step-through passive avoidance experiment consisted of a single training and multiple testing sessions. On Day 24, each rat was placed in the illuminated chamber. After the placement, each rat explored the two compartments freely for $5 \mathrm{~min}$. During the training session on Day 25, the rat was placed in the illuminated compartment for $15 \mathrm{~s}$ before the door was raised. After the rat entered the darkened compartment, the door was closed, and an electrical foot shock was delivered at $0.4 \mathrm{~mA}$ for $2 \mathrm{~s}$. The subject was removed $30 \mathrm{~s}$ after receiving the foot shock and returned to its home cage. During the training session, retention latency for entering the dark compartment was recorded.

The test trials were conducted at the intervals of 1,24 , 48 , and $72 \mathrm{~h}$ after the training session. During the test sessions, the rat was placed in the illuminated compartment, with the guillotine door closed for $30 \mathrm{~s}$. After that, the door was opened, and retention latency for entering the dark compartment and the time spent in both compartments were recorded for $300 \mathrm{~s}$, at which the time, the test was terminated. No electric shock was delivered during the test trials.

\section{Tissue collection}

The animals were sacrificed and decapitated 1 day after the last nicotine injection, and their brains were immediately isolated. Tissues were collected from the hippocampus, PFC, and amygdala according to the rat brain atlas [29]. By using a rat brain matrix, slices of approximately $1.0 \mathrm{~mm}$ were taken from each brain, and tissues from the specific regions of interest were collected bilaterally from each slice with a 3.00-mm Harris Micro-Punch (GE Healthcare Life Sciences, Piscataway, NJ, USA). All punched tissue samples were stored at $-80{ }^{\circ} \mathrm{C}$ until use.

\section{Quantitative RT-PCR (qRT-PCR) array}

We used a custom-designed pathway-focused RT-PCR array with the goal of determining the RNA expression of genes involved in synaptic plasticity. By using the Ingenuity Pathway Analysis (IPA) software (http://ingenuity.com) to search the Kyoto Encyclopedia of Genes and Genome Pathway database (www.genome.jp/kegg/), we selected 80 genes related to synaptic plasticity formation for this custom-designed array. These genes can be grouped into the following biological processes: long-term potentiation (46 genes), long-term depression (25 genes), immediate early gene response (16 genes), cell adhesion (9 genes), extracellular matrix and proteolytic processing (2 genes), Creb signaling (20 genes), and postsynaptic density formation (16 genes).

The primers of each gene selected for the qRT-PCR assay were designed with Primer Express (v. 3.0) software (Applied Biosystems, Carlsbad, CA, USA) and spanned at least one intron to avoid amplifying genomic DNA. The primers had a melting temperature from $59{ }^{\circ} \mathrm{C}$ to $61{ }^{\circ} \mathrm{C}$. Each pair of primers and their amplicon sequences were tested using the Basic Local Alignment Search Tool (BLAST; http://blast.ncbi.nlm.nih.gov/Blast.cgi) to ensure the specificity of the designed primers for the targeted genes. Dissociation curves were generated to check the specificity of the primers before including them in the qRT-PCR array. All primer sequences are listed in Additional file 1: Table S1.

Total RNA was isolated using the Trizol agent (Invitrogen, Carlsbad, CA, USA) according to the manufacturer's protocol. The purity and quantity of total RNA were measured at optical densities of 260 and $280 \mathrm{~nm}$ with NanoDrop 2000c (Thermo Scientific, Waltham, MA, USA). Two $\mu \mathrm{g}$ of total RNA was reverse-transcribed into the first-strand cDNA using Superscript II reverse transcriptase. The cDNA mixture was incubated at $25^{\circ} \mathrm{C}$ for $10 \mathrm{~min}, 42{ }^{\circ} \mathrm{C}$ for $1.5 \mathrm{~h}$, and $70{ }^{\circ} \mathrm{C}$ for $15 \mathrm{~min}$. The PCR amplification was conducted as described previously [30]. Briefly, the product was amplified in a volume of $10 \mu \mathrm{l}$ 
containing $5.0 \mu \mathrm{l}$ of $2 \times$ Power SYBR Green PCR Master Mix (Applied Biosystems) and combined sense and antisense primers $(2.5 \mu \mathrm{l}$; final concentration $20 \mathrm{nM})$ in a 384well plate using the $7900 \mathrm{HT}$ Sequence Detection System (Applied Biosystems). The PCR conditions were as follows: $95{ }^{\circ} \mathrm{C}$ for $10 \mathrm{~min}$, followed by 40 cycles of $95{ }^{\circ} \mathrm{C}$ for $15 \mathrm{~s}$ and $60{ }^{\circ} \mathrm{C}$ for $1 \mathrm{~min}$. A cycle threshold was assigned at the beginning of the logarithmic phase of the amplification, and differences in the $C_{t}$ values of the control and nicotine-treated groups were used to determine the relative expression of genes of interest. Melting curve analysis was applied to characterize the specificity of the amplifications.

\section{Statistical analysis}

Data are expressed as mean \pm S.E.M. For the Y-maze experiments, data were analyzed using one-way analysis of variance (ANOVA) followed by post-hoc Bonferroni analysis. For the results of the passive avoidance test, data were analyzed using the Kruskall-Wallis ANOVA by comparing mean ranks followed by nonparametric analysis with the Mann-Whitney $U$ test. The Kruskall KruskallWallis test is a nonparametric $\mathrm{H}$ test; therefore, the significant result function definitions with this test are presented as $\mathrm{H}$ instead of parametric test script F. Differences were considered statistically significant at $p<0.05$.

Expression of each gene of interest was first normalized to the expression of the housekeeping gene glyceraldehyde-3-phosphate dehydrogenase (GAPDH) and then analyzed using a comparative $C_{t}$ method [31]. The relative expression of each gene was compared within and between HIV-1 $\mathrm{Tg}$ and F344 rats using the Student $t$-test. Significant alteration in mRNA expression was defined as a fold change $>20 \%$ with a $\mathrm{p}$ value $<0.05(\mathrm{~N}=4-6$ per group $)$.

\section{Results}

Improvement of spatial working memory performance by chronic nicotine treatment in the HIV-1Tg and F344 rats

To evaluate the effects of HIV viral proteins and nicotine on spatial working memory performance, spontaneous alternation behavior was tested in the nicotine-treated and saline control groups of both HIV-1Tg and F344 rats. First, there was a significant group difference between the HIV-1Tg_Saline and F344_Saline groups (F $[3,31]=10.83$; $p<0.05$ ) (Fig. 1a). Post hoc analysis revealed that the HIV-1Tg_Saline group showed a low frequency of spontaneous alternation behavior compared with the F344_Saline group $(p<0.01)$.

Chronic daily treatment with nicotine at a dose of $0.4 \mathrm{mg} / \mathrm{kg}$ for 15 days attenuated the viral protein-induced spatial working memory deficit. Spontaneous alternation behavior was significantly higher in the HIV-1Tg_Nicotine group than in the HIV-1Tg_Saline group $(p<0.01)$. No significant difference in the total number of arm entries was detected between the nicotine and control groups of either HIV-1Tg or F344 rats (Fig. 1b). These findings indicate that changes in the alternation behavior in the HIV$1 \mathrm{Tg}$ or F344 rats did not occur as a result of alterations in nicotine-induced locomotor activity.

\section{Chronic nicotine treatment enhanced the contextual memory in HIV-1Tg rats but impaired performance in F344 rats}

The effect of HIV-1 proteins and chronic nicotine treatment on the contextual memory performance was
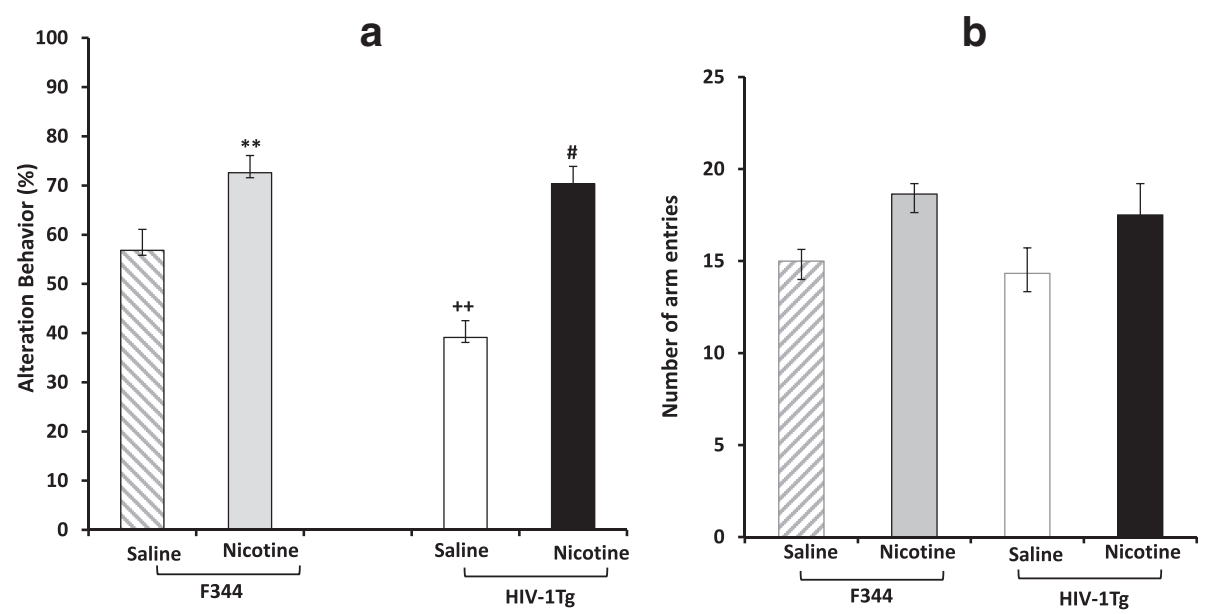

Fig. 1 Nicotine effects on spatial working memory. a Spontaneous alteration behavior. $\mathbf{b}$ Number of arm entries during an eight-min session in the Y-maze task on day 15 ( $\mathrm{N}=9-12$ /group). Vertical bars show mean \pm S.E.M. ${ }^{* *},{ }^{++} p<0.01$ compared with F344 saline-treated rats; ${ }^{\#} p<0.01$ compared with HIV-1Tg nicotine-treated rats 


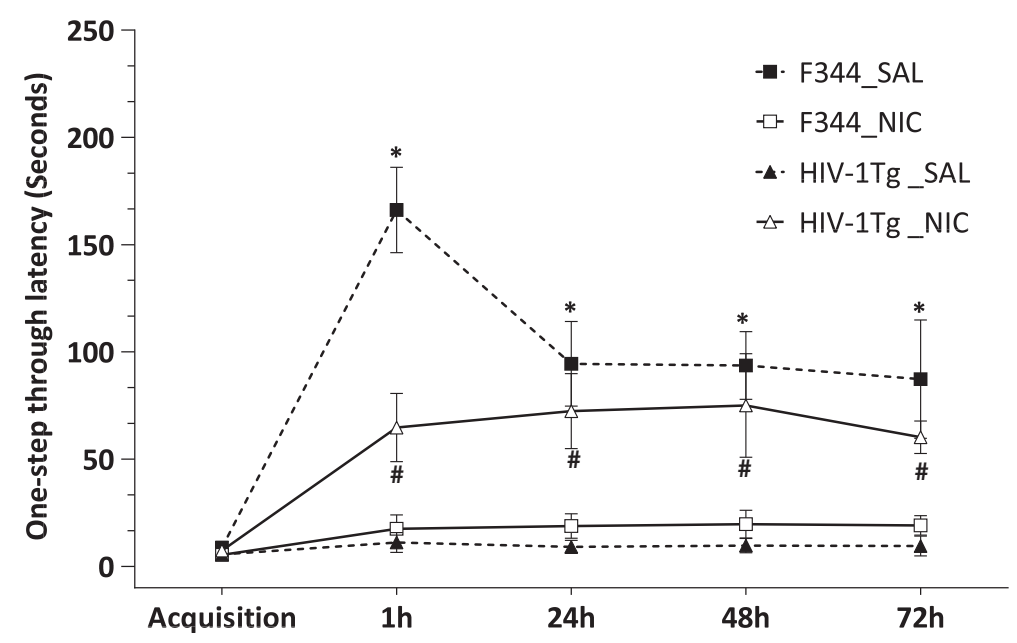

Fig. 2 Effects of nicotine on step-through latency in the multiple-trial passive avoidance task on Days 22-26 in F344 and HIV-1Tg rats. Rats received daily nicotine injections five-min before the behavioral test ( $N=9-12 /$ group). Data are shown as mean \pm S.E.M of the one-step through avoidance latencies at 1, 24, 48, and $72 \mathrm{~h}$ after the foot shock. ${ }^{*} p<0.05$ in difference from F344-nicotine treated group; ${ }^{\#} p<0.05$ in difference from HIV-1Tg saline-treated group (Mann-Whitney U-test)

assessed by the one-step-through passive avoidance test in both rat strains. In the acquisition trial, we found no significant difference between the nicotine- and salinetreated groups of either F344 or HIV-1Tg rats (Fig. 2). However, there was a significant strain difference in the one-step-through latency in the $1,24,48$, and $72 \mathrm{~h}$ retention trials $(\mathrm{H}=9.12, p<0.05 ; \mathrm{H}=14.74, p<0.01 ; \mathrm{H}=$ $7.89, p<0.05 ; \mathrm{H}=8.50, p<0.05$, respectively). Nicotine prolonged the latency of entering the dark box in the HIV-1Tg rats, but impaired the passive avoidance behavior in F344 rats. Non-parametric analysis by the MannWhitney $U$ test revealed that the HIV-1Tg_Nicotine group showed a significant increase in one-step-through latency at 24, 48, and $72 \mathrm{~h}$ compared with their control group $(p<0.05)$. In the F344 rats, chronic nicotine treatment induced a significant reduction in the one-stepthrough latency in the retention trials compared with the control group $(p<0.05)$.

\section{HIV-1 proteins altered the expression of synaptic plasticity genes in a brain region-specific manner} To determine the effect of HIV-1 proteins on the expression of genes related to synaptic plasticity, we analyzed the expression of the 80 genes in the qRT-PCR array. We found significant expression differences between the two strains on 16 genes in the hippocampus, 17 genes in the PFC, and 12 genes in the amygdala, respectively, which were classified into six signaling pathways in the hippocampus and five in the PFC or amygdala region of the HIV-1Tg_Saline group (Table 1).

The HIV-1 proteins altered the expression of genes encoding members of mGluR-mediated PLC/IP3-mediated calcium signaling, with 36\%-78 \% significant upregulation of Grm 5, Plcb4, and ltpr3 in the hippocampus and $19 \%-$ $30 \%$ significant downregulation of Grm1, Plcb4, Itpr1, and Itpr2 in the PFC (Table 1; Fig. 3a, b). In the voltagedependent $\mathrm{Ca}^{+} 2$ channel (VDCC)-mediated calcium signaling and $\mathrm{Ca}^{+2} /$ calmodulin-dependent kinase signaling pathways, viral proteins significantly upregulated the expression of Cacnali, Calm4, and Camk4, by $20 \%-50 \%$, in the hippocampus but downregulated the expression of Cacnalg and Camk $2 g$ by $68 \%$ and $79 \%$, respectively, in the PFC and of Cacnalg and Calm 2 by $63 \%$ and $71 \%$, respectively, in the amygdala (Table 1). We did not observe significant alterations in response to viral proteins in the expression of genes involved in Creb signaling in the PFC and amygdala, but there was significant upregulation $(43 \%)$ of the expression of transcription factor Creb2 by viral proteins in the hippocampus (Fig. 3a).

Expression of genes involved in the MAP kinase signaling pathway and synapse formation was significantly changed by viral proteins in all three brain regions. In the MAP kinase pathway, viral proteins significantly decreased the expression of Mapk3, by $19 \%$, in the hippocampus; of Raf1, Map2k1, and Mapk3, by $18 \%-27 \%$ in the PFC; and of the same genes, by $27 \%-31 \%$ in the amygdala. There was a significant decrease in the expression of genes associated with immediate early response and postsynaptic density formation in the hippocampus and amygdala (Table 1). Together, these results indicate that HIV-1 proteins exert a brain regionspecific modulation of the expression of genes involved in intracellular calcium signaling and calmodulindependent kinase signaling pathways. 
Table 1 HIV-1 viral proteins induced significant alterations in the expression of synaptic plasticity genes. A total of 80 synaptic plasticity genes were analyzed using a qRT-PCR-array analysis. Among them, 50 showed significant strain-specific expression $(p<0.05$ and fold change $>20 \%$ ) in the hippocampus, prefrontal cortex, or amygdala

\begin{tabular}{|c|c|c|c|c|c|c|}
\hline Signaling Pathway & Gene Name & Molecular Function & $\begin{array}{l}\text { F344_Saline } \\
(\text { Mean } \pm \text { S.E.M) }\end{array}$ & $\begin{array}{l}\text { HIV-1Tg_Saline } \\
(\text { Mean } \pm \text { S.E.M) }\end{array}$ & $\begin{array}{l}\text { Ratio (HIV- } \\
\text { 1Tg/F344) } \\
\text { Saline }\end{array}$ & $P$ Value \\
\hline \multicolumn{7}{|l|}{ Hippocampus } \\
\hline \multirow{3}{*}{$\begin{array}{l}\text { Metabotropic glutamate receptor } \\
\text { mediated PLC/IP3-dependent } \\
\text { calcium signaling }\end{array}$} & Grm5 & $\begin{array}{l}\text { Metabotropic glutamate } \\
\text { receptor activity }\end{array}$ & $4.4 \mathrm{E}-02 \pm 3.4 \mathrm{E}-03$ & $6.0 \mathrm{E}-02 \pm 2.1 \mathrm{E}-03$ & 1.36 & 0.004 \\
\hline & Plcb4 & Phospholipase C activity & $2.4 \mathrm{E}-02 \pm 2.2 \mathrm{E}-04$ & $3.9 \mathrm{E}-04 \pm 3.8 \mathrm{E}-04$ & 1.63 & 0.005 \\
\hline & Itpr3 & $\begin{array}{l}\text { Calcium ion transmembrane } \\
\text { transporter activity }\end{array}$ & $7.3 \mathrm{E}-04 \pm 1.5 \mathrm{E}-04$ & $1.3 \mathrm{E}-03 \pm 1.5 \mathrm{E}-04$ & 1.78 & 0.02 \\
\hline \multirow[t]{3}{*}{$\begin{array}{l}\mathrm{Ca}^{+2} / \mathrm{calmodulin} \text {-dependent protein } \\
\text { kinase signaling }\end{array}$} & Cacna1i & $\begin{array}{l}\text { Voltage-gated calcium } \\
\text { channel activity }\end{array}$ & $2.0 \mathrm{E}-03 \pm 3.6 \mathrm{E}-04$ & $3.0 \mathrm{E}-03 \pm 2.1 \mathrm{E}-04$ & 1.5 & 0.04 \\
\hline & Camk4 & $\begin{array}{l}\text { Calmodulin dependent } \\
\text { protein kinase activity }\end{array}$ & $3.3 \mathrm{E}-02 \pm 1.1 \mathrm{E}-03$ & $3.9 \mathrm{E}-02 \pm 1.7 \mathrm{E}-03$ & 1.2 & 0.02 \\
\hline & Calm4 & Calcium ion binding & $2.6 \mathrm{E}-03 \pm 3.1 \mathrm{E}-04$ & $3.7 \mathrm{E}-03 \pm 2.5 \mathrm{E}-04$ & 1.42 & 0.03 \\
\hline CREB signaling & Creb-2 (Atf4) & $\begin{array}{l}\text { Transcription } \\
\text { factor activity }\end{array}$ & $8.0 \mathrm{E}-03 \pm 2.8 \mathrm{E}-04$ & $1.2 \mathrm{E}-02 \pm 4.4 \mathrm{E}-04$ & 1.57 & 0.01 \\
\hline \multirow[t]{3}{*}{ Kinase signaling } & Akt1 (PKB) & Protein kinase activity & $2.7 \mathrm{E}-02 \pm 2.4 \mathrm{E}-03$ & 4.0E-02 $\pm 2.6 \mathrm{E}-03$ & 1.48 & 0.006 \\
\hline & Mapk3 & $\begin{array}{l}\text { Mitogen activated } \\
\text { kinase activity }\end{array}$ & $9.6 \mathrm{E}-02 \pm 8.0 \mathrm{E}-03$ & $7.2 \mathrm{E}-02 \pm 6.5 \mathrm{E}-03$ & 0.74 & 0.03 \\
\hline & Adcy8 & $\begin{array}{l}\text { Adenylate cyclase } \\
\text { activity }\end{array}$ & $7.6 \mathrm{E}-03 \pm 4.2 \mathrm{E}-04$ & $6.1 \mathrm{E}-03 \pm 6.0 \mathrm{E}-04$ & 0.80 & 0.033 \\
\hline \multirow[t]{4}{*}{ Immediate early response gene } & Arc & Actin binding & $1.2 \mathrm{E}-02 \pm 2.0 \mathrm{E}-02$ & $6.2 \mathrm{E}-03 \pm 1.2 \mathrm{E}-03$ & 0.49 & 0.03 \\
\hline & Bdnf & Growth factor activity & $4.2 \mathrm{E}-04 \pm 5.0 \mathrm{E}-05$ & $2.3 \mathrm{E}-04 \pm 7.1 \mathrm{E}-05$ & 0.56 & 0.02 \\
\hline & Jun-b & $\begin{array}{l}\text { Transcription factor } \\
\text { activity }\end{array}$ & $1.5 \mathrm{E}-02 \pm 2.2 \mathrm{E}-03$ & $9.9 \mathrm{E}-03 \pm 7.5 \mathrm{E}-04$ & 0.63 & 0.03 \\
\hline & $\mathrm{Ngf}$ & Growth factor activity & $6.5 \mathrm{E}-03 \pm 4.7 \mathrm{E}-04$ & $4.9 \mathrm{E}-03 \pm 4.8 \mathrm{E}-04$ & 0.75 & 0.01 \\
\hline \multirow[t]{2}{*}{ Postsynaptic organization of synapse } & Gria1 & Glutamate receptor activity & $2.2 \mathrm{E}-01 \pm 2.4 \mathrm{E}-02$ & $1.5 \mathrm{E}-01 \pm 1.7 \mathrm{E}-02$ & 0.69 & 0.006 \\
\hline & Adam10 & Metallopeptidase activity & $2.6 \mathrm{E}-02 \pm 1.6 \mathrm{E}-03$ & $1.9 \mathrm{E}-01 \pm 2.0 \mathrm{E}-03$ & 0.74 & 0.04 \\
\hline \multicolumn{7}{|l|}{ Prefrontal Cortex } \\
\hline \multirow{4}{*}{$\begin{array}{l}\text { Metabotropic glutamate receptor } \\
\text { mediated PLC/IP3-dependent } \\
\text { calcium signaling }\end{array}$} & Grm1 & $\begin{array}{l}\text { Metabotropic glutamate } \\
\text { receptor activity }\end{array}$ & $5.6 \mathrm{E}-02 \pm 8.0 \mathrm{E}-03$ & $3.3 \mathrm{E}-02 \pm 5.5 \mathrm{E}-03$ & 0.58 & 0.03 \\
\hline & Plcb4 & Phospholipase $\mathrm{C}$ activity & $2.0 \mathrm{E}-02 \pm 1.2 \mathrm{E}-04$ & $1.4 \mathrm{E}-02 \pm 5.8 \mathrm{E}-04$ & 0.70 & 0.002 \\
\hline & Itpr1 & $\begin{array}{l}\text { Calcium lon transmembrane } \\
\text { transporter activity }\end{array}$ & $7.0 \mathrm{E}-03 \pm 7.9 \mathrm{E}-04$ & $5.0 \mathrm{E}-03 \pm 4.9 \mathrm{E}-04$ & 0.71 & 0.04 \\
\hline & Itrp2 & $\begin{array}{l}\text { Calcium lon transmembrane } \\
\text { transporter activity }\end{array}$ & $1.5 \mathrm{E}-01 \pm 1.2 \mathrm{E}-02$ & $1.2 \mathrm{E}-01 \pm 1.5 \mathrm{E}-03$ & 0.81 & 0.03 \\
\hline \multirow[t]{3}{*}{$\begin{array}{l}\mathrm{Ca}^{+2} / \mathrm{calmodulin}^{-} \text {dependent } \\
\text { kinase signaling }\end{array}$} & Cacna1g & $\begin{array}{l}\text { Voltage-gated calcium } \\
\text { channel activity }\end{array}$ & $2.6 \mathrm{E}-02 \pm 2.4 \mathrm{E}-03$ & $1.7 \mathrm{E}-02 \pm 1.0 \mathrm{E}-03$ & 0.68 & 0.01 \\
\hline & Camk2g & $\begin{array}{l}\text { Calmodulin-dependent } \\
\text { kinase activity }\end{array}$ & $2.6 \mathrm{E}-02 \pm 1.8 \mathrm{E}-03$ & $2.0 \mathrm{E}-02 \pm 3.5 \mathrm{E}-04$ & 0.79 & 0.02 \\
\hline & Cdh2 & Calcium ion binding activity & $6.9 \mathrm{E}-02 \pm 1.2 \mathrm{E}-02$ & $3.2 \mathrm{E}-02 \pm 2.5 \mathrm{E}-03$ & 0.46 & 0.01 \\
\hline \multirow[t]{7}{*}{ Kinase signaling } & Map2k1 & MAP kinase activity & $1.2 \mathrm{E}-01 \pm 1.0 \mathrm{E}-02$ & $9.2 \mathrm{E}-02 \pm 4.2 \mathrm{E}-03$ & 0.73 & 0.02 \\
\hline & Mapk3 & MAP kinase activity & $6.6 \mathrm{E}-02 \pm 3.9 \mathrm{E}-03$ & $5.4 \mathrm{E}-02 \pm 2.1 \mathrm{E}-03$ & 0.81 & 0.03 \\
\hline & Raf1 & MAP kinase kinase activity & $2.0 \mathrm{E}-02 \pm 7.0 \mathrm{E}-04$ & $1.6 \mathrm{E}-02 \pm 1.0 \mathrm{E}-03$ & 0.82 & 0.03 \\
\hline & Prkacb & Protein kinase A activity & $1.9 \mathrm{E}-02 \pm 1.3 \mathrm{E}-03$ & $1.5 \mathrm{E}-02 \pm 7.5 \mathrm{E}-04$ & 0.79 & 0.04 \\
\hline & Akt1 & Akt kinase activity & $4.2 \mathrm{E}-02 \pm 2.6 \mathrm{E}-03$ & $3.4 \mathrm{E}-02 \pm 1.6 \mathrm{E}-03$ & 0.80 & 0.03 \\
\hline & JNK1 & $\begin{array}{l}\text { C-Jun N-terminal protein } \\
\text { kinase }\end{array}$ & $1.3 \mathrm{E}-01 \pm 3.4 \mathrm{E}-03$ & $1.9 \mathrm{E}-01 \pm 4.3 \mathrm{E}-03$ & 1.46 & 0.02 \\
\hline & $\|-6$ & Cytokine activity & $1.5 \mathrm{E}-04 \pm 1.5 \mathrm{E}-05$ & $7.4 \mathrm{E}-05 \pm 9.8 \mathrm{E}-06$ & 0.48 & 0.002 \\
\hline
\end{tabular}


Table 1 HIV-1 viral proteins induced significant alterations in the expression of synaptic plasticity genes. A total of 80 synaptic plasticity genes were analyzed using a qRT-PCR-array analysis. Among them, 50 showed significant strain-specific expression ( $p<0.05$ and fold change $>20 \%$ ) in the hippocampus, prefrontal cortex, or amygdala (Continued)

\begin{tabular}{|c|c|c|c|c|c|c|}
\hline \multirow{2}{*}{$\begin{array}{l}\text { Inflammation-mediated } \\
\text { neurodegenera-tive } \\
\text { signaling }\end{array}$} & $\mathrm{CCl} 2$ & Chemokine activity & $2.0 \mathrm{E}-04 \pm 2.4 \mathrm{E}-05$ & $1.2 \mathrm{E}-04 \pm 1.2 \mathrm{E}-05$ & 0.61 & 0.02 \\
\hline & Gabra5 & GABA-A receptor activity & $4.3 \mathrm{E}-02 \pm 2.1 \mathrm{E}-03$ & $3.3 \mathrm{E}-02 \pm 2.5 \mathrm{E}-03$ & 0.77 & 0.02 \\
\hline Postsynaptic density formation & Gria1 & Glutamate receptor activity & $8.4 \mathrm{E}-02 \pm 4.5 \mathrm{E}-03$ & $6.6 \mathrm{E}-02 \pm 1.0 \mathrm{E}-03$ & 0.79 & 0.02 \\
\hline \multicolumn{7}{|l|}{ Amygdala } \\
\hline $\begin{array}{l}\text { lonotropic glutamate receptor- } \\
\text { mediated } \mathrm{Ca}^{+2} \text { signaling }\end{array}$ & Grin1 & $\begin{array}{l}\text { lonotropic glutamate } \\
\text { receptor activity }\end{array}$ & $1.4 \mathrm{E}-01 \pm 7.1 \mathrm{E}-01$ & $1.0 \mathrm{E}-01 \pm 8.3 \mathrm{E}-03$ & 0.76 & 0.01 \\
\hline \multirow[t]{2}{*}{$\begin{array}{l}\mathrm{Ca}^{+2} / \text { calmodulin-dependent } \\
\text { kinase signaling }\end{array}$} & Cacnalg & $\begin{array}{l}\text { Voltage-gated calcium } \\
\text { channel activity }\end{array}$ & 2.7E-01 $\pm 2.4 \mathrm{E}-03$ & $1.7 \mathrm{E}-02 \pm 5.0 \mathrm{E}-04$ & 0.63 & 0.006 \\
\hline & Calm2 & Calcium ion binding & $1.0 \pm 7.5 \mathrm{E}-02$ & $7.4 \mathrm{E}-01 \pm 2.8 \mathrm{E}-02$ & 0.71 & 0.01 \\
\hline \multirow[t]{3}{*}{ Kinase signaling } & Mapk1 & MAP kinase activity & 2.7E-01 $\pm 2.2 \mathrm{E}-02$ & 1.7E-01 $\pm 1.0 \mathrm{E}-03$ & 0.61 & 0.02 \\
\hline & Mapk3 & MAP kinase activity & $9.3 \mathrm{E}-02 \pm 9.4 \mathrm{E}-03$ & $6.2 \mathrm{E}-02 \pm 2.9 \mathrm{E}-03$ & 0.67 & 0.01 \\
\hline & Raf1 & $\begin{array}{l}\text { MAP kinase kinase } \\
\text { kinase activity }\end{array}$ & $2.5 \mathrm{E}-02 \pm 1.5 \mathrm{E}-03$ & 1.7E-02 $\pm 8.6 \mathrm{E}-04$ & 0.69 & 0.02 \\
\hline \multirow[t]{2}{*}{ Immediate early gene response } & Ntrk2 & Growth factor activity & $4.3 \mathrm{E}-03 \pm 5.7 \mathrm{E}-04$ & $2.5 \mathrm{E}-03 \pm 2.1 \mathrm{E}-04$ & 0.57 & 0.01 \\
\hline & Junb & $\begin{array}{l}\text { Transcription factor } \\
\text { activity }\end{array}$ & $1.5 \mathrm{E}-02 \pm 2.2 \mathrm{E}-03$ & $9.9 \mathrm{E}-03 \pm 7.6 \mathrm{E}-04$ & 0.63 & 0.03 \\
\hline \multirow[t]{4}{*}{$\begin{array}{l}\text { Postsynaptic organization of } \\
\text { synapse }\end{array}$} & Gria3 & $\begin{array}{l}\text { lonotropic glutamate } \\
\text { receptor activity (AMPA) }\end{array}$ & $4.1 \mathrm{E}-02 \pm 3.5 \mathrm{E}-3$ & $2.6 \mathrm{E}-02 \pm 2.7 \mathrm{E}-03$ & 0.63 & 0.02 \\
\hline & Adam10 & Metallopeptidase activity & $2.6 \mathrm{E}-02 \pm 1.6 \mathrm{E}-03$ & $1.9 \mathrm{E}-02 \pm 2.0 \mathrm{E}-03$ & 0.74 & 0.04 \\
\hline & Gria1 & $\begin{array}{l}\text { Ionotropic glutamate } \\
\text { receptor activity (AMPA) }\end{array}$ & $1.3 \mathrm{E}-01 \pm 3.5 \mathrm{E}-03$ & $1.0 \mathrm{E}-01 \pm 5.3 \mathrm{E}-03$ & 0.83 & 0.02 \\
\hline & Dlg4 & Scaffold protein binding & $2.5 \mathrm{E}-01 \pm 2.9 \mathrm{E}-01$ & $1.2 \mathrm{E}-01 \pm 6.4 \mathrm{E}-03$ & 0.46 & 0.003 \\
\hline
\end{tabular}

Nicotine alters the synaptic plasticity gene expression in the cortico-limbic circuits of HIV-1Tg rats

Next, we wanted to determine how nicotine impacts the expression of genes involved in synaptic plasticity in HIV$1 \mathrm{Tg}$ rats. We found that nicotine significantly altered the expression of 22, 15, and 11 genes, respectively, in the hippocampus, PFC, and amygdala (Table 2). A gene ontology (GO) analysis of these genes showed that those significantly altered by nicotine can be classified into eight, five, and six signaling pathways in the hippocampus, PFC, and amygdala, respectively.

Chronic nicotine treatment significantly decreased the expression of Plcb4, Itpr1, and Itpr3, by $16 \%-68 \%$, in the hippocampus, of Plcb3 and Itpr3, by18 \%-35\%, in the PFC, and of Plcb4, by $36 \%$ in the amygdala (Fig. 4 and Additional file 2: Figure S1a). In the $\mathrm{Ca}^{+2} /$ calmodulindependent kinase signaling pathway, nicotine significantly downregulated the expression of Camk4 and Camk $2 g$, by $20 \%$, in the hippocampus but upregulated the expression of Camk2b, Camk4, Cancna1i, and Calm3, by $14 \%-82 \%$, in the PFC and of Cacna1g, Camk2a, and Camk4, by $59 \%-72 \%$, in the amygdala. In Ras/MEK/ERK signaling pathway, nicotine significantly upregulated the expression of Mapk3, Mapk1, Map2k1, and Kras, by $22 \%-67 \%$, in the hippocampus and downregulated the expression of $\operatorname{Map} 2 k 2, \operatorname{Map} 2 k 1$,
Mapk3, and Braf, by $14 \%-33 \%$, in the PFC and of Kras, by $23 \%$, in the amygdala (Table 2).

Consistent with the increased expression of hippocampal MAPK genes, expression of Creb and its cofactors was changed in nicotine-treated HIV-1Tg rats, with $34 \%-$ $45 \%$ upregulation of Creb1 and Cebpb in the hippocampus, $17 \%-28 \%$ downregulation of Cebpb and Creb2 in the PFC, and $34 \%-82 \%$ upregulation of Cebpb and its target MMP-9 in the amygdala (Table 2; Fig. 4a and b). Further, chronic nicotine treatment reversed the effect of viral proteins on the expression of Creb2, which was decreased by $35 \%$ in the hippocampus of HIV-1Tg rats.

\section{Nicotine displays distinct effects on synaptic plasticity gene expression in F344 rats}

The same set of genes was analyzed in the hippocampus, PFC, and amygdala of F344 rats in order to determine whether nicotine had the same effects on expression of the genes related to synaptic plasticity under normal physiological condition. Among the 80 genes examined, we found that 14 in the hippocampus, 18 in PFC, and 12 in the amygdala, respectively, were differentially expressed in the nicotine-treated and saline control groups (Table 3 ). The GO analysis showed that nicotine altered four, six, and four signaling pathways in the hippocampus, PFC, and amygdala, respectively (Table 3 ). 


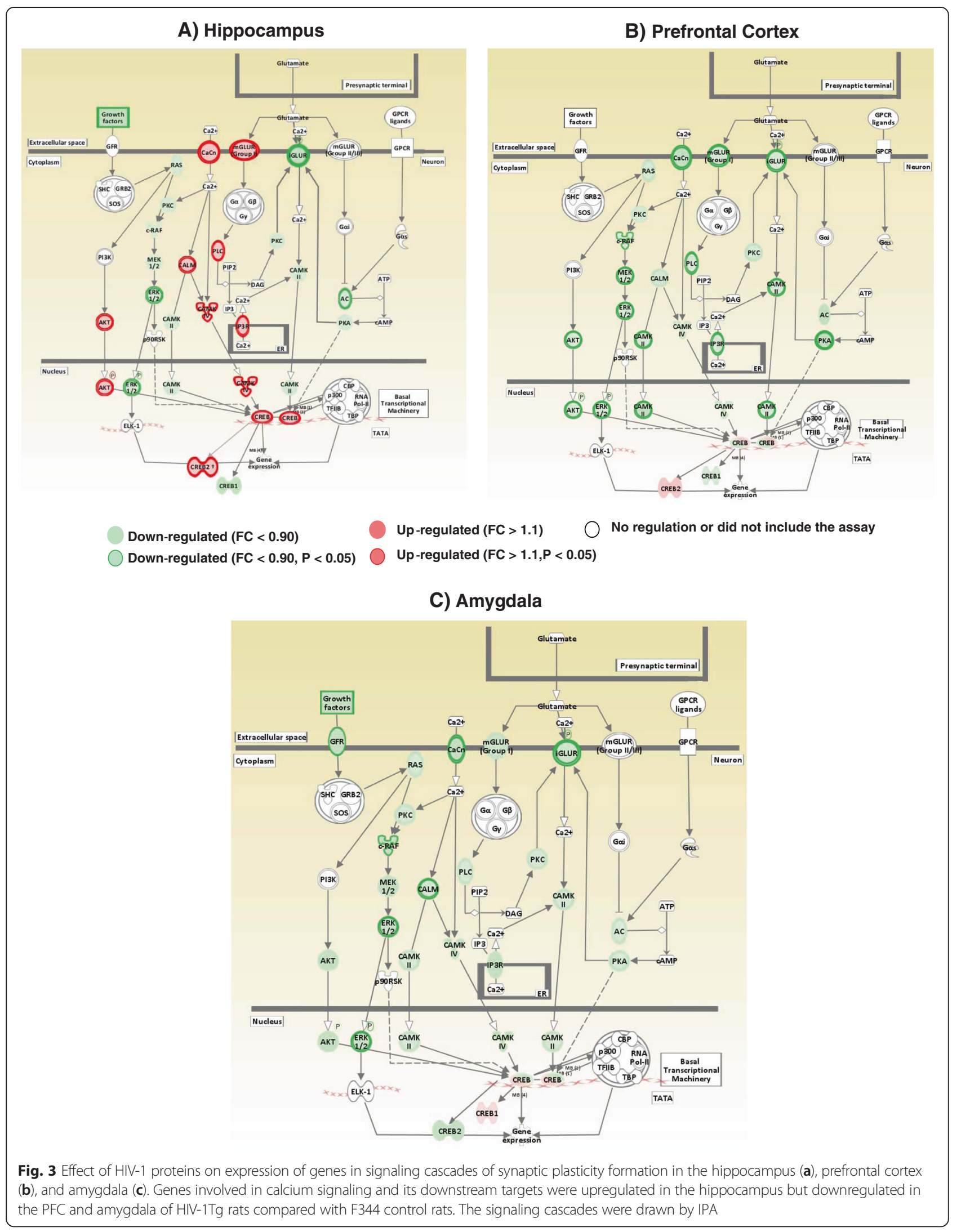


Table 2 Nicotine-induced alterations in expression of synaptic plasticity genes in the hippocampus, PFC, and amygdala of the HIV-1Tg rats. Genes exhibited significant alterations in the brain following chronic nicotine treatment in HIV-1Tg rats $(p<0.05$ and fold ratio $>20 \%$ ). Differential effects of nicotine on the gene expression determined by comparing the HIV-1Tg nicotine-treated group with HIV-1Tg saline group (Student's t-test with Bonferroni correction)

\begin{tabular}{|c|c|c|c|c|c|c|}
\hline Signaling Pathway & Gene Name & Molecular Function & $\begin{array}{l}\text { HIV-1Tg_Saline } \\
\text { (Mean } \pm \text { S.E.M) }\end{array}$ & $\begin{array}{l}\text { HIV-1Tg_Nicotine } \\
\text { (Mean } \pm \text { S.E.M) }\end{array}$ & $\begin{array}{l}\text { (HIV-1Tg_ } \\
\text { Saline/ HIV- } \\
\text { 1Tg_Nicotine) }\end{array}$ & $P$ Value \\
\hline \multicolumn{7}{|l|}{ Hippocampus } \\
\hline \multirow{2}{*}{$\begin{array}{l}\text { lonotropic glutamate receptor- } \\
\text { mediated } \mathrm{Ca}^{+2} \text { influx }\end{array}$} & Grin2a & lonotropic glutamate receptor & $1.0 \mathrm{E}-01 \pm 3.4 \mathrm{E}-03$ & $9.1 \mathrm{E}-2 \pm 4.9 \mathrm{E}-03$ & 0.86 & 0.04 \\
\hline & Grin2b & Ionotropic glutamate receptor & $2.8 \mathrm{E}-01 \pm 5.1 \mathrm{E}-03$ & $2.2 \mathrm{E}-1 \pm 1.2 \mathrm{E}-02$ & 0.88 & 0.04 \\
\hline \multirow[t]{2}{*}{$\begin{array}{l}\mathrm{Ca}^{+2} / \text { calmodulin-dependent } \\
\text { kinase signaling }\end{array}$} & Camk4 & $\begin{array}{l}\text { Calmodulin-dependent } \\
\text { protein kinase activity }\end{array}$ & $3.9 \mathrm{E}-02 \pm 1.7 \mathrm{E}-03$ & $3.2 \mathrm{E}-2 \pm 1.9 \mathrm{E}-03$ & 0.80 & 0.02 \\
\hline & Camk2g & $\begin{array}{l}\text { Calmodulin-dependent } \\
\text { protein kinase activity }\end{array}$ & $2.5 \mathrm{E}-02 \pm 5.8 \mathrm{E}-04$ & $2.0 \mathrm{E}-02 \pm 3.6 \mathrm{E}-04$ & 0.80 & 0.03 \\
\hline \multirow[t]{3}{*}{ PLC/IP3-mediated calcium signaling } & Plcb4 & Phospholipase C activity & $3.9 \mathrm{E}-04 \pm 3.8 \mathrm{E}-04$ & $2.1 \mathrm{E}-04- \pm 3.8 \mathrm{E}-03$ & 0.52 & 0.007 \\
\hline & Itpr3 & $\begin{array}{l}\text { Calcium ion transmembrane } \\
\text { transporter activity }\end{array}$ & $1.3 \mathrm{E}-03 \pm 1.5 \mathrm{E}-04$ & $8.9 \mathrm{E}-04 \pm 9.0 \mathrm{E}-05$ & 0.64 & 0.03 \\
\hline & Itpr1 & $\begin{array}{l}\text { Calcium ion transmembrane } \\
\text { transporter activity }\end{array}$ & $7.2 \mathrm{E}-02 \pm 4.2 \mathrm{E}-03$ & $6.0 \mathrm{E}-02 \pm 1.5 \mathrm{E}-03$ & 0.84 & 0.03 \\
\hline \multirow[t]{3}{*}{ CREB signaling } & Creb-2 (Atf4) & Transcription factor activity & $1.1 \mathrm{E}-02 \pm 4.4 \mathrm{E}-04$ & $8.3 \mathrm{E}-03 \pm 4.2 \mathrm{E}-04$ & 0.65 & 0.001 \\
\hline & Creb-1 & Transcription factor activity & $2.3 \mathrm{E}-02 \pm 5.0 \mathrm{E}-04$ & $3.4 \mathrm{E}-02 \pm 1.8 \mathrm{E}-03$ & 1.45 & 0.02 \\
\hline & Cbp & Transcription factor activity & $3.3 \mathrm{E}-04 \pm 2.5 \mathrm{E}-05$ & 4.4E-04 $\pm 2.7 \mathrm{E}-05$ & 1.34 & 0.01 \\
\hline \multirow[t]{7}{*}{ Kinase signaling } & Jnk1 & C-Jun N-terminal protein kinase & $1.2 \mathrm{E}-02 \pm 5.2 \mathrm{E}-04$ & $1.0 \mathrm{E}-02 \pm 4.7 \mathrm{E}-04$ & 0.85 & 0.04 \\
\hline & Mapk3 & MAP kinase activity & $7.2 \mathrm{E}-02 \pm 6.5 \mathrm{E}-03$ & $8.8 \mathrm{E}-02 \pm 4.8 \mathrm{E}-03$ & 1.22 & 0.03 \\
\hline & Adcy 1 & Adenylate cyclase activity & $2.5 \mathrm{E}-01 \pm 1.4 \mathrm{E}-02$ & $3.2 \mathrm{E}-01 \pm 7.0 \mathrm{E}-03$ & 1.28 & 0.004 \\
\hline & Mapk1 & MAP kinase activity & $1.8 \mathrm{E}-01 \pm 2.3 \mathrm{E}-02$ & $2.4 \mathrm{E}-01 \pm 4.2 \mathrm{E}-03$ & 1.33 & 0.04 \\
\hline & Map2k1 & MAP kinase activity & $1.6 \mathrm{E}-01 \pm 7.8 \mathrm{E}-03$ & $2.2 \mathrm{E}-01 \pm 7.3 \mathrm{E}-03$ & 1.37 & 0.005 \\
\hline & Prkacb & Protein kinase $\mathrm{A}$ activity & $9.5 \mathrm{E}-02 \pm 2.0 \mathrm{E}-03$ & $1.4 \mathrm{E}-01 \pm 4.2 \mathrm{E}-03$ & 1.53 & 0.001 \\
\hline & Kras & GTPase activity & $3.3 \mathrm{E}-02 \pm 2.8 \mathrm{E}-03$ & $5.3 \mathrm{E}-02 \pm 3.2 \mathrm{E}-03$ & 1.62 & 0.002 \\
\hline $\begin{array}{l}\text { Immediate early gene } \\
\text { response }\end{array}$ & Nurr & Transcription factor activity & $6.6 \mathrm{E}-03 \pm 4.6 \mathrm{E}-04$ & $8.2 \mathrm{E}-03 \pm 5.6 \mathrm{E}-04$ & 1.25 & 0.02 \\
\hline \multirow[t]{2}{*}{ Postsynaptic organization of synapse } & Synpo & Actin binding & $4.9 \mathrm{E}-02 \pm 2.5 \mathrm{E}-03$ & $5.8 \mathrm{E}-02 \pm 9.9 \mathrm{E}-04$ & 1.14 & 0.04 \\
\hline & Gria2 & $\begin{array}{l}\text { lonotropic glutamate } \\
\text { receptor activity (AMPA) }\end{array}$ & $1.6 \mathrm{E}-01 \pm 2.1 \mathrm{E}-01$ & $2.4 \mathrm{E}-01 \pm 2.0 \mathrm{E}-02$ & 1.55 & 0.03 \\
\hline $\begin{array}{l}\text { Inflammation-mediated } \\
\text { neurodegenerative signaling }\end{array}$ & $\mathrm{Ccl} 2$ & Chemokine activity & $1.2 \mathrm{E}-04 \pm 1.3 \mathrm{E}-05$ & $8.1 \mathrm{E}-5 \pm 6.9 \mathrm{E}-06$ & 0.63 & 0.02 \\
\hline \multicolumn{7}{|l|}{ Prefrontal Cortex } \\
\hline \multirow{2}{*}{$\begin{array}{l}\text { lonotropic glutamate receptor } \\
\text { mediated } \mathrm{Ca}^{+2} \text { influx }\end{array}$} & Grin2a & lonotropic glutamate receptor & $8.8 \mathrm{E}-02 \pm 9.9 \mathrm{E}-03$ & $5.1 \mathrm{E}-02 \pm 2.9 \mathrm{E}-04$ & 0.58 & 0.01 \\
\hline & Grin2c & lonotropic glutamate receptor & $1.0 \mathrm{E}-02 \pm 8.2 \mathrm{E}-04$ & $7.0 \mathrm{E}-03 \pm 4.6 \mathrm{E}-04$ & 0.64 & 0.001 \\
\hline \multirow[t]{4}{*}{$\begin{array}{l}\mathrm{Ca}^{+2} / \mathrm{calmodulin} \text {-dependent } \\
\text { kinase signaling }\end{array}$} & Camk2b & $\begin{array}{l}\text { Calmodulin-dependent } \\
\text { protein kinase activity }\end{array}$ & $0.1 .7 \mathrm{E}-01 \pm 1.0 \mathrm{E}-02$ & $2.9 \mathrm{E}-01 \pm 2.3 \mathrm{E}-03$ & 1.67 & 0.004 \\
\hline & Camk4 & $\begin{array}{l}\text { Calmodulin-dependent } \\
\text { protein kinase activity }\end{array}$ & $3.1 \mathrm{E}-02 \pm 2.0 \mathrm{E}-03$ & $5.3 \mathrm{E}-02 \pm 9.3 \mathrm{E}-04$ & 1.69 & 0.001 \\
\hline & Cacna1i & $\begin{array}{l}\text { Voltage-gated calcium } \\
\text { channel activity }\end{array}$ & $1.7 \mathrm{E}-02 \pm 1.0 \mathrm{E}-03$ & $3.2 \mathrm{E}-02 \pm 1.7 \mathrm{E}-03$ & 1.82 & 0.003 \\
\hline & Calm3 & Calcium ion binding & $6.0 \mathrm{E}-01 \pm 1.1 \mathrm{E}-02$ & 7.2E-01 $\pm 2.7 \mathrm{E}-02$ & 1.14 & 0.01 \\
\hline \multirow[t]{2}{*}{ PLC/IP3-mediated calcium signaling } & Plcb3 & Phospholipase $\mathrm{C}$ activity & $2.2 \mathrm{E}-03 \pm 2.4 \mathrm{E}-04$ & $1.4 \mathrm{E}-03 \pm 1.2 \mathrm{E}-04$ & 0.65 & 0.01 \\
\hline & Itpr3 & $\begin{array}{l}\text { Calcium ion transmembrane } \\
\text { transporter activity }\end{array}$ & $4.5 \mathrm{E}-03 \pm 2.5 \mathrm{E}-04$ & $3.7 \mathrm{E}-03 \pm 2.1 \mathrm{E}-04$ & 0.82 & 0.02 \\
\hline \multirow[t]{2}{*}{ Kinase signaling } & Map2k2 & MAP kinase activity & $1.3 \mathrm{E}-03 \pm 7.5 \mathrm{E}-05$ & $9.3 \mathrm{E}-04 \pm 1.4 \mathrm{E}-05$ & 0.67 & 0.005 \\
\hline & Map2k1 & MAP kinase activity & $9.4 \mathrm{E}-02 \pm 5.2 \mathrm{E}-03$ & $6.5 \mathrm{E}-01 \pm 3.2 \mathrm{E}-03$ & 0.69 & 0.002 \\
\hline
\end{tabular}


Table 2 Nicotine-induced alterations in expression of synaptic plasticity genes in the hippocampus, PFC, and amygdala of the HIV-1Tg rats. Genes exhibited significant alterations in the brain following chronic nicotine treatment in HIV-1Tg rats $(p<0.05$ and fold ratio $>20 \%$ ). Differential effects of nicotine on the gene expression determined by comparing the HIV-1Tg nicotine-treated group with HIV-1Tg saline group (Student's t-test with Bonferroni correction) (Continued)

\begin{tabular}{|c|c|c|c|c|c|c|}
\hline & Braf & MAP kinase kinase activity & $3.1 \mathrm{E}-01 \pm 1.0 \mathrm{E}-03$ & $2.3 \mathrm{E}-02 \pm 1.1 \mathrm{E}-03$ & 0.75 & 0.001 \\
\hline & Mapk3 & MAP kinase activity & $5.4 \mathrm{E}-02 \pm 2.1 \mathrm{E}-03$ & 4.7E-02 $\pm 1.1 \mathrm{E}-03$ & 0.86 & 0.04 \\
\hline & Akt1 & Akt kinase activity & $3.4 \mathrm{E}-02 \pm 1.6 \mathrm{E}-03$ & $5.2 \mathrm{E}-02 \pm 5.2 \mathrm{E}-03$ & 1.55 & 0.04 \\
\hline \multirow[t]{2}{*}{ CREB signaling } & Crem & Transcription factor activity & $5.3 \mathrm{E}-03 \pm 2.4 \mathrm{E}-04$ & $3.8 \mathrm{E}-03 \pm 4.1 \mathrm{E}-04$ & 0.72 & 0.04 \\
\hline & Creb2 & Transcription factor activity & $1.5 \mathrm{E}-02 \pm 8.5 \mathrm{E}-04$ & $1.2 \mathrm{E}-02 \pm 4.8 \mathrm{E}-04$ & 0.83 & 0.03 \\
\hline \multicolumn{7}{|l|}{ Amygdala } \\
\hline \multirow{2}{*}{$\begin{array}{l}\text { lonotropic glutamate receptor } \\
\text { mediated } \mathrm{Ca}^{+2} \text { influx }\end{array}$} & Grin2d & lonotropic glutamate receptor & $1.9 \mathrm{E}-02 \pm 1.9 \mathrm{E}-03$ & $1.4 \mathrm{E}-02 \pm 1.0 \mathrm{E}-03$ & 0.76 & 0.04 \\
\hline & Grin2b & lonotropic glutamate receptor & $1.3 \mathrm{E}-01 \pm 7.2 \mathrm{E}-03$ & $1.0 \mathrm{E}-01 \pm 7.3 \mathrm{E}-03$ & 0.80 & 0.04 \\
\hline \multirow[t]{3}{*}{$\begin{array}{l}\mathrm{Ca}^{+2} / \text { calmodulin-dependent } \\
\text { kinase signaling }\end{array}$} & Cacna1g & $\begin{array}{l}\text { Voltage-gated calcium } \\
\text { channel activity }\end{array}$ & $1.7 \mathrm{E}-02 \pm 5.0 \mathrm{E}-04$ & $2.7 \mathrm{E}-02 \pm 2.4 \mathrm{E}-03$ & 1.59 & 0.006 \\
\hline & Camk2a & $\begin{array}{l}\text { Calmodulin-dependent } \\
\text { protein kinase activity }\end{array}$ & $1.4 \mathrm{E}-01 \pm 3.6 \mathrm{E}-01$ & $2.4 \mathrm{E}-01 \pm 1.7 \mathrm{E}-01$ & 1.66 & 0.001 \\
\hline & Camk4 & $\begin{array}{l}\text { Calmodulin-dependent } \\
\text { protein kinase activity }\end{array}$ & $1.5 \mathrm{E}-02 \pm 1.0 \mathrm{E}-03$ & $2.6 \mathrm{E}-03 \pm 3.4 \mathrm{E}-03$ & 1.72 & 0.02 \\
\hline \multirow[t]{2}{*}{ PLC/IP3-mediated calcium signaling } & Plcb4 & Phospholipase C activity & $2.3 \mathrm{E}-02 \pm 2.3 \mathrm{E}-03$ & $1.5 \mathrm{E}-02 \pm 2.7 \mathrm{E}-03$ & 0.64 & 0.04 \\
\hline & Calm2 & Calcium ion binding & $7.4 \mathrm{E}-01 \pm 2.8 \mathrm{E}-02$ & $5.9 \mathrm{E}-01 \pm 1.9 \mathrm{E}-02$ & 0.80 & 0.02 \\
\hline \multirow[t]{2}{*}{ Kinase signaling } & Kras & GTPase activity & $4.1 \mathrm{E}-02 \pm 2.8 \mathrm{E}-03$ & $3.2 \mathrm{E}-03 \pm 2.5 \mathrm{E}-03$ & 0.77 & 0.04 \\
\hline & Prkacb & Protein kinase $A$ activity & $1.5 \mathrm{E}-01 \pm 8.3 \mathrm{E}-03$ & $2.4 \mathrm{E}-01 \pm 1.3 \mathrm{E}-03$ & 1.55 & 0.001 \\
\hline CREB signaling & $\mathrm{Cbp}$ & Transcription factor activity & $3.3 \mathrm{E}-04 \pm 2.5 \mathrm{E}-05$ & 4.4E-04 $\pm 2.7 \mathrm{E}-05$ & 1.34 & 0.01 \\
\hline Immediate early gene response & Mmp-9 & Metallopeptidase activity & $7.1 \mathrm{E}-05 \pm 1.2 \mathrm{E}-05$ & $1.3 \mathrm{E}-04 \pm 2.0 \mathrm{E}-05$ & 1.82 & 0.03 \\
\hline
\end{tabular}

The genes involved in PLC/IP3-mediated calcium signaling were significantly downregulated by nicotine in the three brain regions of F344 rats $(P=0.01-0.04)$ (Table 3). However, nicotine showed bidirectional effects on the expression of genes involved in VDCC-mediated calcium signaling and the $\mathrm{Ca}^{+2} /$ calmodulin-dependent kinase signaling pathway, with $46 \%-57 \%$ upregulation of Camk4 and Cacnali expression in the hippocampus, $20 \%-25 \%$ upregulation of Calm1 and Camk2g expression in the amygdala, and $56 \%-73 \%$ downregulation of Camk2b, Camk4, Calm2, and Cacna1g expression in the PFC (Fig. 5 and Additional file 2: Figure S1b). The expression of genes involved in the Map kinase and $\mathrm{AC} /$ PKA signaling pathways was also significantly altered by nicotine in F344 rats. In the Raf/MEK/ERK signaling pathway, nicotine significantly downregulated the expression of Raf1, Mapk1, and Map2k2, by $25 \%-73 \%$, in the hippocampus, of Raf1 and Mapk3, by $72 \%$ and $74 \%$, respectively, in the PFC, and of Raf1, by $72 \%$, and Mapk1, by $55 \%$, in the amygdala. In the AC/PKA signaling, nicotine significantly decreased the expression of Adcy 1 , by $22 \%$, and Prkacb, by $80 \%$, in the hippocampus but increased the expression of $A d c y 1$ by $26 \%$ and of Prkacb by $15 \%$ in the PFC (Table 3). We also observed nicotine-induced brain region-specific expression alterations in the immediate early gene response. For example, nicotine significantly upregulated expression of $A r c$ and
Mmp-9 in the hippocampus and of Ngf and Synpo in the PFC but downregulated the expression of transcription factors Fos-b, Fos, Jun-b, and Egr1 and their downstream targets BDNF and Ntrk2 in the amygdala (Table 3 and Fig. 5b).

\section{Discussion}

The current study provides detailed information on the effects of HIV-1 proteins and nicotine on expression of synaptic plasticity genes in the hippocampal-PFCamygdala-dependent learning and memory mechanisms. The principal findings of this study are: (1) HIV-1 proteins impaired the hippocampal-PFC-dependent spatial working and hippocampal-amygdala-dependent contextual fear memory in HIV-1Tg rats (see Figs. 1 and 2); (2) the upstream regulators and downstream targets of intracellular calcium signaling were altered by HIV-1 proteins in a brain region-specific manner (see Fig. 3 and Table 1); (3) chronic nicotine treatment improved the spatial working and contextual fear memory performance in HIV-1Tg rats (Figs. 1 and 2) and attenuated the effect of viral proteins on synaptic plasticity formation in a brain region-specific manner (see Fig. 4 and Table 2); and (4) the effect of nicotine on the gene expression of synaptic plasticity and contextual fear memory formation differed significantly between the HIV-1Tg and F344 control rats. Nicotine 


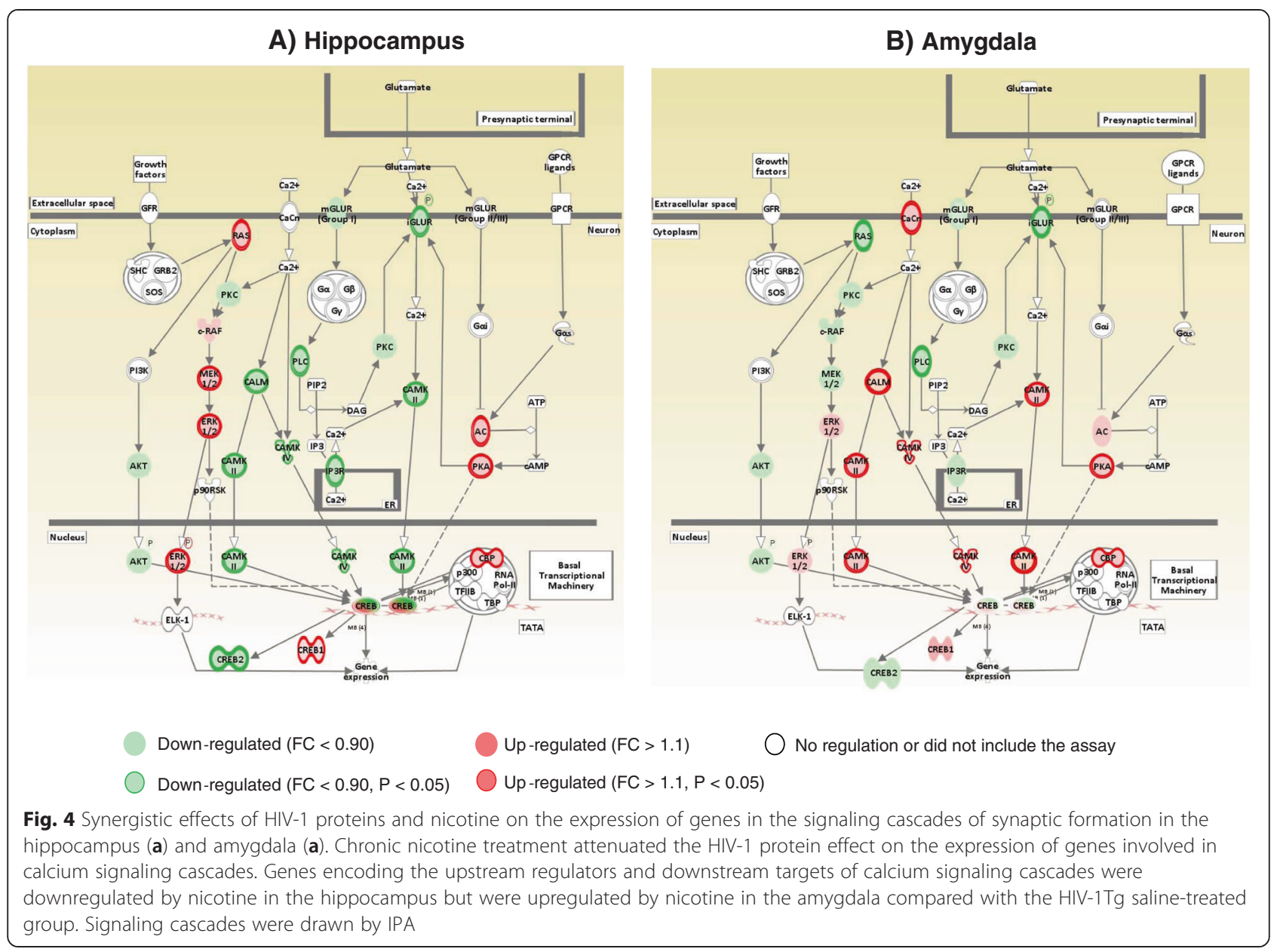

impaired the contextual learning and related gene expression in the amygdala of the F344 rats (Fig. 2; Table 3). Together, these findings indicate that nicotine as a cholinergic channel modulator can attenuate HIV-1 effects on synaptic plasticity and memory formation, and the effect of hippocampal-amygdaladependent contextual fear memory differed in the healthy (i.e., F344 rats) and disease (i.e., HIV-1Tg rats) states.

HIV-1 proteins disturb synaptic plasticity formation in the hippocampus-PFC-amygdala circuit and impair the working and contextual memory in HIV-1Tg rats

Typically, HAND occurs in the early stages of HIV-1 infection and causes slow performance in the encoding and retrieval of spatial and contextual related information [5]. The HIV-1Tg rat expresses seven of the nine HIV genes and shows neurological and cognitive complications similar to those observed in HAND patients [32-34]. The non-infective HIV-1Tg rat offers a valid model for investigating the neuropathological aspects of memory impairment in HAND patients. Specifically, in this study, we showed that viral proteins induced a deficit in both spatial working and contextual memory performance in these animals. As shown in Figures 1a and 2, HIV-1Tg rats exhibited low spontaneous alteration behavior in the Y-maze and short latency in entering the dark box during the retention trials of the one-step-through passive avoidance test compared with the F344 control rats. Given that the HIV-1Tg rats show strong neuropathological similarities to HIV-1-infected patients with concomitant expression of multiple HIV genes, the observed memory deficits in HIV-1Tg rats are most likely the result of the neurodegenerative effects of multiple HIV-1 proteins within the neural circuits of learning and memory.

Glutamate-mediated excitotoxicity has been considered a central pathological mechanism for the effects of HIV-1 proteins on the neurodegenerative process in the brain [16]. These proteins lead to glutamate-induced deregulation of calcium homeostasis by over-activating the glutamate receptors and facilitating neurodegeneration in the brain $[17,18,35,36]$. When an excessive amount of glutamate is released from the microglia and presynaptic neurons during the neurodegeneration, the calcium conductance of NMDA receptors is inhibited by intracellular calcium through calcium sensitive proteins 
Table 3 Effect of nicotine on expression of genes involved in synaptic plasticity in the hippocampus, PFC, and amygdala of F344 rats. Significant expression alterations were determined by comparing the F344 nicotine-treated group with the F344 saline-treated group (Student's t-test with Bonferroni correction). Significance set as $p<0.05$ and fold ratio $>20 \%$

\begin{tabular}{|c|c|c|c|c|c|c|}
\hline Signaling Pathway & $\begin{array}{l}\text { Gene } \\
\text { Name }\end{array}$ & Molecular Function & $\begin{array}{l}\text { F344_Saline } \\
(\text { Mean } \pm \text { S.E.M) }\end{array}$ & $\begin{array}{l}\text { F344_Nicotine } \\
(\text { Mean } \pm \text { S.E.M) }\end{array}$ & $\begin{array}{l}\text { Ratio (F344_- } \\
\text { Saline/F344_ } \\
\text { Nicotine) }\end{array}$ & $P$ Value \\
\hline \multicolumn{7}{|l|}{ Hippocampus } \\
\hline \multirow[t]{2}{*}{$\begin{array}{l}\mathrm{Ca}^{+2} / \mathrm{calmodulin}^{-} \text {dependent } \\
\text { kinase signaling }\end{array}$} & Camk4 & $\begin{array}{l}\text { Calmodulin-dependent protein } \\
\text { kinase activity }\end{array}$ & $3.3 \mathrm{E}-02 \pm 1.1 \mathrm{E}-03$ & $5.2 \mathrm{E}-02 \pm 9.4 \mathrm{E}-04$ & 1.57 & 0.007 \\
\hline & Cacna1i & $\begin{array}{l}\text { Voltage-gated calcium channel } \\
\text { activity }\end{array}$ & $2.0 \mathrm{E}-03 \pm 3.6 \mathrm{E}-04$ & $2.9 \mathrm{E}-03 \pm 1.1 \mathrm{E}-04$ & 1.46 & 0.03 \\
\hline PLC/IP3-mediated calcium signaling & Plcb4 & Phospholipase $\mathrm{C}$ activity & $2.4 \mathrm{E}-02 \pm 2.2 \mathrm{E}-04$ & $1.5 \mathrm{E}-02 \pm 2.2 \mathrm{E}-03$ & 0.66 & 0.02 \\
\hline \multirow[t]{6}{*}{ Kinase signaling } & Hras & GTPase activity & $8.7 \mathrm{E}-06 \pm 2.2 \mathrm{E}-06$ & 4.1E-06 $\pm 1.7 \mathrm{E}-05$ & 0.47 & 0.04 \\
\hline & Prkacb & Protein kinase A activity & $1.9 \mathrm{E}-02 \pm 1.3 \mathrm{E}-03$ & $1.5 \mathrm{E}-02 \pm 1.6 \mathrm{E}-03$ & 0.82 & 0.02 \\
\hline & Adcy 1 & Adenylate cyclase activity & $3.3 \mathrm{E}-01 \pm 2.1 \mathrm{E}-02$ & $2.6 \mathrm{E}-01 \pm 2.1 \mathrm{E}-02$ & 0.78 & 0.006 \\
\hline & Mapk1 & MAP kinase activity & $4.3 \mathrm{E}-01 \pm 2.1 \mathrm{E}-02$ & $5.4 \mathrm{E}-01 \pm 4.3 \mathrm{E}-03$ & 1.25 & 0.01 \\
\hline & Raf1 & MAP kinase kinase activity & $2.0 \mathrm{E}-02 \pm 7.0 \mathrm{E}-04$ & $3.0 \mathrm{E}-02 \pm 2.1 \mathrm{E}-03$ & 1.52 & 0.01 \\
\hline & Map2k2 & MAP kinase activity & $2.3 \mathrm{E}-03 \pm 1.7 \mathrm{E}-04$ & $4.0 \mathrm{E}-03 \pm 2.4 \mathrm{E}-04$ & 1.73 & 0.001 \\
\hline \multirow[t]{5}{*}{ Immediate early response gene } & Ntrk2 & Neurotrophin receptor activity & $2.0 \mathrm{E}-03 \pm 3.0 \mathrm{E}-04$ & $1.1 \mathrm{E}-03 \pm 5.1 \mathrm{E}-05$ & 0.53 & 0.04 \\
\hline & Egr1 & Transcription factor activity & $9.4 \mathrm{E}-02 \pm 9.6 \mathrm{E}-03$ & $5.3 \mathrm{E}-02 \pm 5.7 \mathrm{E}-03$ & 0.55 & 0.03 \\
\hline & Jun-b & Transcription factor activity & $1.5 \mathrm{E}-02 \pm 2.2 \mathrm{E}-03$ & $9.0 \mathrm{E}-03 \pm 1.3 \mathrm{E}-03$ & 0.57 & 0.02 \\
\hline & Arc & $\begin{array}{l}\text { Activity-regulated cytoskeleton- } \\
\text { associated protein }\end{array}$ & $1.2 \mathrm{E}-02 \pm 2.0 \mathrm{E}-03$ & $7.9 \mathrm{E}-03 \pm 8.0 \mathrm{E}-04$ & 0.63 & 0.03 \\
\hline & Mmp9 & Metallopeptidase activity & $9.6 \mathrm{E}-05 \pm 1.3 \mathrm{E}-05$ & $1.8 \mathrm{E}-04 \pm 3.5 \mathrm{E}-05$ & 1.87 & 0.02 \\
\hline \multicolumn{7}{|l|}{ Prefrontal Cortex } \\
\hline \multirow{2}{*}{$\begin{array}{l}\text { Ionotropic glutamate receptor- } \\
\text { mediated } \mathrm{Ca}^{+2} \text { influx }\end{array}$} & Grin2c & Ionotropic glutamate receptor & $1.1 \mathrm{E}-02 \pm 1.1 \mathrm{E}-03$ & $8.5 \mathrm{E}-03 \pm 5.2 \mathrm{E}-04$ & 0.72 & 0.04 \\
\hline & Grin2d & Ionotropic glutamate receptor & 4.0E-03 $\pm 7.6 \mathrm{E}-05$ & $3.0 \mathrm{E}-03 \pm 1.0 \mathrm{E}-04$ & 0.76 & 0.03 \\
\hline \multirow[t]{4}{*}{$\begin{array}{l}\mathrm{Ca}^{+2} / \text { calmodulin-dependent } \\
\text { kinase signaling }\end{array}$} & Camk2b & $\begin{array}{l}\text { Calmodulin-dependent protein } \\
\text { kinase activity }\end{array}$ & $1.7 \mathrm{E}-01 \pm 1.0 \mathrm{E}-02$ & $2.9 \mathrm{E}-01 \pm 2.3 \mathrm{E}-03$ & 1.67 & 0.004 \\
\hline & Cacna1g & $\begin{array}{l}\text { Voltage-gated calcium channel } \\
\text { activity }\end{array}$ & $2.6 \mathrm{E}-02 \pm 2.4 \mathrm{E}-03$ & $4.0 \mathrm{E}-02 \pm 2.5 \mathrm{E}-03$ & 1.56 & 0.004 \\
\hline & Camk4 & $\begin{array}{l}\text { Calmodulin-dependent protein } \\
\text { kinase activity }\end{array}$ & $3.3 \mathrm{E}-02 \pm 2.1 \mathrm{E}-03$ & $5.3 \mathrm{E}-02 \pm 3.3 \mathrm{E}-03$ & 1.60 & 0.002 \\
\hline & Calm2 & Calcium ion binding & 4.4E-01 $\pm 6.0 \mathrm{E}-02$ & $7.8 \mathrm{E}-01 \pm 3.9 \mathrm{E}-02$ & 1.73 & 0.001 \\
\hline \multirow[t]{3}{*}{$\begin{array}{l}\text { PLC/IP3-mediated calcium } \\
\text { signaling }\end{array}$} & Itpr2 & $\begin{array}{l}\text { Calcium ion transmembrane } \\
\text { transporter activity }\end{array}$ & $7.0 \mathrm{E}-03 \pm 7.9 \mathrm{E}-04$ & $4.6 \mathrm{E}-03 \pm 3.3 \mathrm{E}-04$ & 0.66 & 0.04 \\
\hline & Plcb3 & Phospholipase C activity & $3.0 \mathrm{E}-03 \pm 2.4 \mathrm{E}-04$ & $2.0 \mathrm{E}-03 \pm 2.6 \mathrm{E}-04$ & 0.68 & 0.03 \\
\hline & Itpr1 & $\begin{array}{l}\text { Calcium ion transmembrane } \\
\text { transporter activity }\end{array}$ & $7.0 \mathrm{E}-03 \pm 7.9 \mathrm{E}-04$ & $5.1 \mathrm{E}-01 \pm 6.9 \mathrm{E}-04$ & 0.73 & 0.01 \\
\hline \multirow[t]{5}{*}{ Kinase signaling } & Raf1 & MAP kinase kinase activity & $2.0 \mathrm{E}-02 \pm 7.0 \mathrm{E}-04$ & $1.4 \mathrm{E}-02 \pm 1.8 \mathrm{E}-03$ & 0.72 & 0.03 \\
\hline & Mapk3 & MAP kinase activity & $6.6 \mathrm{E}-02 \pm 3.9 \mathrm{E}-03$ & $4.9 \mathrm{E}-02 \pm 1.1 \mathrm{E}-03$ & 0.74 & 0.006 \\
\hline & Prkacb & Protein kinase A activity & $1.9 \mathrm{E}-02 \pm 1.3 \mathrm{E}-03$ & $2.3 \mathrm{E}-02 \pm 4.7 \mathrm{E}-03$ & 1.15 & 0.01 \\
\hline & Akt1 & Akt kinase activity & $4.2 \mathrm{E}-02 \pm 2.6 \mathrm{E}-03$ & $5.0 \mathrm{E}-02 \pm 3.1 \mathrm{E}-03$ & 1.26 & 0.02 \\
\hline & Adcy8 & Adenylate cyclase activity & $3.9 \mathrm{E}-03 \pm 4.2 \mathrm{E}-04$ & $5.1 \mathrm{E}-03 \pm 2.4 \mathrm{E}-04$ & 1.31 & 0.02 \\
\hline \multirow[t]{2}{*}{ Immediate early response gene } & Synpo & Actin binding & $3.4 \mathrm{E}-02 \pm 2.6 \mathrm{E}-03$ & $4.4 \mathrm{E}-02 \pm 2.8 \mathrm{E}-03$ & 1.27 & 0.04 \\
\hline & $\mathrm{Ngf}$ & Growth factor activity & $1.5 \mathrm{E}-03 \pm 1.6 \mathrm{E}-04$ & $1.9 \mathrm{E}-03 \pm 7.2 \mathrm{E}-05$ & 1.29 & 0.03 \\
\hline \multirow{2}{*}{$\begin{array}{l}\text { Inflammation-mediated } \\
\text { neurodegenerative signaling }\end{array}$} & $\|-6$ & Cytokine activity & $1.5 \mathrm{E}-4 \pm 1.5 \mathrm{E}-05$ & $7.0 \mathrm{E}-05 \pm 7.8 \mathrm{E}-06$ & 0.45 & 0.001 \\
\hline & Tnf & Cytokine activity & $4.2 \mathrm{E}-04 \pm 1.1 \mathrm{E}-04$ & $3.0 \mathrm{E}-04 \pm 2.8 \mathrm{E}-05$ & 0.70 & 0.04 \\
\hline \multicolumn{7}{|l|}{ Amygdala } \\
\hline & Calm1 & Calcium ion binding & $1.2 \pm 9.0 \mathrm{E}-02$ & $9.2 \mathrm{E}-01 \pm 7.8 \mathrm{E}-02$ & 0.75 & 0.04 \\
\hline
\end{tabular}


Table 3 Effect of nicotine on expression of genes involved in synaptic plasticity in the hippocampus, PFC, and amygdala of F344 rats. Significant expression alterations were determined by comparing the F344 nicotine-treated group with the F344 saline-treated group (Student's t-test with Bonferroni correction). Significance set as $p<0.05$ and fold ratio $>20 \%$ (Continued)

\begin{tabular}{|c|c|c|c|c|c|c|}
\hline $\begin{array}{l}\mathrm{Ca}^{+2} / \mathrm{calmodulin}-\text { dependent } \\
\text { kinase signaling }\end{array}$ & Camk2g & $\begin{array}{l}\text { Calmodulin-dependent } \\
\text { protein kinase activity }\end{array}$ & $3.2 \mathrm{E}-2 \pm 2.4 \mathrm{E}-03$ & $2.5 \mathrm{E}-02 \pm 1.6 \mathrm{E}-03$ & 0.80 & 0.04 \\
\hline \multirow[t]{2}{*}{ PLC/IP3-mediated calcium signaling } & Itpr2 & $\begin{array}{l}\text { Calcium ion transmembrane } \\
\text { transporter activity }\end{array}$ & $6.8 \mathrm{E}-03 \pm 4.2 \mathrm{E}-04$ & $5.5 \mathrm{E}-03 \pm 1.0 \mathrm{E}-04$ & 0.80 & 0.02 \\
\hline & Itpr3 & $\begin{array}{l}\text { Calcium ion transmembrane } \\
\text { transporter activity }\end{array}$ & $3.6 \mathrm{E}-03 \pm 3.4 \mathrm{E}-04$ & 3.0E-03 $\pm 7.7 \mathrm{E}-05$ & 0.82 & 0.03 \\
\hline \multirow[t]{2}{*}{ Kinase signaling } & Mapk1 & MAP kinase activity & $2.7 \mathrm{E}-01 \pm 2.2 \mathrm{E}-02$ & $1.5 \mathrm{E}-01 \pm 2.0 \mathrm{E}-01$ & 0.55 & 0.007 \\
\hline & Raf1 & MAP kinase kinase activity & $2.5 \mathrm{E}-02 \pm 1.5 \mathrm{E}-03$ & $1.8 \mathrm{E}-02 \pm 2.0 \mathrm{E}-03$ & 0.72 & 0.02 \\
\hline \multirow[t]{6}{*}{ Immediate early response gene } & Fos-b & Transcription factor activity & $1.0 \mathrm{E}-02 \pm 3.2 \mathrm{E}-03$ & $3.8 \mathrm{E}-03 \pm 9.7 \mathrm{E}-04$ & 0.38 & 0.03 \\
\hline & Junb & Transcription factor activity & $1.5 \mathrm{E}-02 \pm 2.2 \mathrm{E}-0$ & $8.0 \mathrm{E}-03 \pm 1.4 \mathrm{E}-03$ & 0.51 & 0.02 \\
\hline & Egr1 & Transcription factor binding activity & $9.4 \mathrm{E}-02 \pm 9.7 \mathrm{E}-03$ & $5.8 \mathrm{E}-02 \pm 3.8 \mathrm{E}-03$ & 0.61 & 0.01 \\
\hline & Ntrk2 & Neurotrophin receptor activity & $4.3 \mathrm{E}-03 \pm 5.7 \mathrm{E}-04$ & $2.6 \mathrm{E}-03 \pm 1.9 \mathrm{E}-04$ & 0.61 & 0.02 \\
\hline & Bdnf & Growth factor activity & $9.2 \mathrm{E}-05 \pm 5.3 \mathrm{E}-06$ & $5.8 \mathrm{E}-05 \pm 1.6 \mathrm{E}-05$ & 0.63 & 0.03 \\
\hline & Fos & Transcription factor activity & $3.0 \mathrm{E}-03 \pm 5.0 \mathrm{E}-04$ & $1.9 \mathrm{E}-03 \pm 2.0 \mathrm{E}-04$ & 0.63 & 0.04 \\
\hline
\end{tabular}

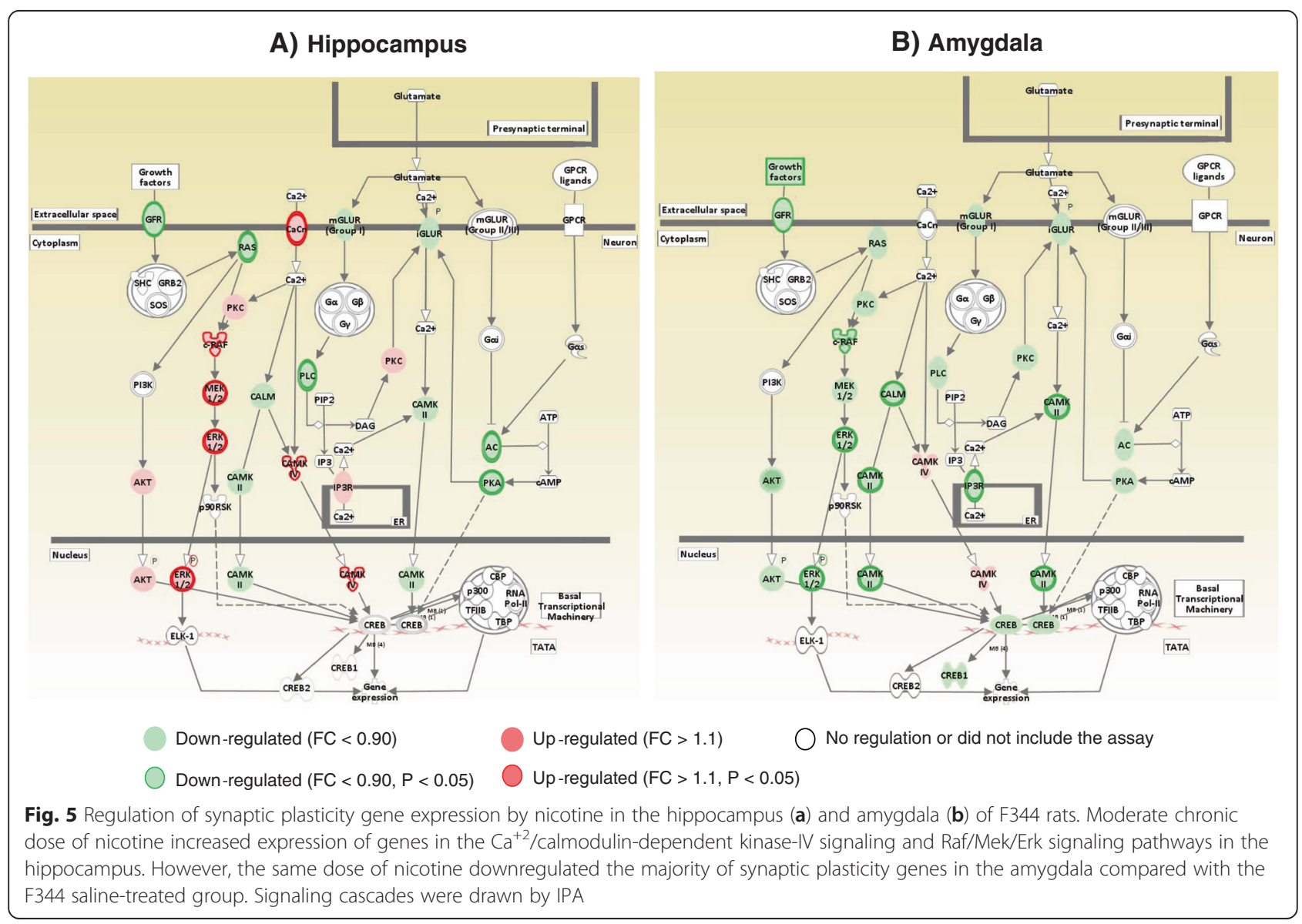


[37]. The calcium-induced NMDA receptor inactivation serves as a negative feedback mechanism and results in downregulation of NMDA receptors [38-40]. Here, we demonstrated that HIV-1Tg rats showed significant downregulation of NMDA receptor subunits in the hippocampus, PFC and amygdala (Fig. 1). This result suggests the activation of the negative feedback loop, which could operate as a physiological homeostatic mechanism to limit the level of neurotoxicity caused by viral proteins. However, this type of protection may also limit the level of neuronal activity in HIV-1Tg rats that may contribute to spatial and contextual memory deficit. Further, our gene expression data showed the selective effects of viral proteins on the expression of genes in the intracellular calcium signaling pathways. As shown Figure $3 a$, viral proteins significantly upregulated the expression of genes involved in mGluR5-mediated calcium signaling but downregulated the expression of immediate early genes (IEGs) in the hippocampus. These results support previous studies, which showed that low expression of IEG mRNAs was associated with mGluRdependent long-term depression (LTD) formation in the hippocampus [41-43]. However, HIV-1 proteins decreased calcium signaling in the PFC and amygdala by downregulating genes in the VDCC- and PLC/IP3-mediated calcium signaling pathways (Fig. $3 \mathrm{~b}, \mathrm{c}$ ). Considerable evidence demonstrates that dysfunction in VDCC and IP3 receptor activity plays a central role in synaptic loss and memory impairment during neurodegeneration in the brain. In particular, reduction in calcium signaling inhibits onset of LTP and long-term memory acquisition through deactivation of calcium-sensitive Ras/ERK and CAMK signaling pathways $[44,45]$. We confirmed the aforementioned findings in cognitively impaired HIV$1 \mathrm{Tg}$ rats by showing the low expression of VDCC and IP3 receptor genes with significant downregulation in the calcium-sensitive protein kinase signaling pathways in both the PFC and the amygdala (see Table 1).

The results presented here clearly show that HIV-1 proteins display a brain region-specific effect on calcium signaling, which may be considered an important factor causing synaptic plasticity dysfunction and memory impairment in HIV-1Tg rats. One possible explanation for this effect is that HIV-1 proteins enhance hippocampal LTD induction by overactivating mGluRs-PLC/IP3- mediated calcium signaling through excessive release of glutamate from the microglia cells. The viral proteins mediate this deregulation of calcium signaling and may facilitate the synaptic loss and reduce the hippocampal synaptic projections to the PFC and amygdala. Low hippocampal presynaptic stimulation of the PFC and amygdala circuits could reduce the LTP induction that is mediated by calcium entry through VDCC in the neurons of the PFC and amygdala. Further, in support of the link between hippocampal LTD and LTP formation in the PFC and amygdala of HIV-1Tg rats, blocking LTP induction in the hippocampus inhibits LTP formation in the medial PFC-basolateral amygdala [46]. These alterations are associated with memory impairment during brain neurodegeneration $[47,48]$.

\section{Chronic nicotine treatment attenuates the effects of HIV-1 proteins on synaptic plasticity and enhances working and contextual memory in HIV-1Tg rats}

Nicotine as well as other nicotinic receptor agonists show neuroprotective effects against glutamate-mediated neurotoxicity and enhance cognitive performance in a variety of neurodegenerative disorders $[25,49,50]$. As such, this cognitive-enhancing effect of nicotine is defined as one of the main reasons that hinder efforts to quit smoking in HIV-1-infected patients [7]. Nicotine received through cigarette smoking in these patients preassumely increases the risk for HIV-1 infection related disease progression and mortality [7]. Therefore, determination of the molecular mechanisms underlying cognitive-enhancing and neuroprotective effects of nicotine in this particular population will provide new insights into potential drug treatment.

Nicotine can affect glutamatergic neurotransmission directly through nAChRs and indirectly through VDCC and IP3 receptors and modulate calcium signaling in glutamatergic neurons [51, 52]. However, the regulatory effects of nicotine on these calcium signaling pathways depend on the distribution of $\mathrm{nAChRs}$ and baseline intracellular calcium concentrations among the brain regions during neurodegeneration. Neuronal nicotinic acetylcholine receptors can contribute to modify the function of ionotropic glutamate receptors. Stimulation of $\alpha 7$ and $\beta 2$ nicotinic acetylcholine receptors by cholinergic agonists decreases the surface expression of the NMDA receptor subunits during the glutamate toxicity. Shen et al. [53] reported that pre-treatment of nicotine abolished the glutamate-induced calcium influx by modulating surface expression of NMDA receptors through kinase signaling. Our results showed that chronic nicotine treatment significantly decreased expression of NMDA receptor subunits in the hippocampus, PFC, and amygdala of HIV-1Tg rats, as compared with their saline-treated counterparts (Fig. 4 and Additional file 2: Figure S1a). This suggests that nicotine may engage with negative feedback mechanisms in response to NMDA receptor activitydependent calcium influx and contribute to limit the levels of neurotoxicity within neural circuits of learning and memory.

Our findings also showed that chronic nicotine treatment attenuated the effects of HIV-1 proteins on spatial working and contextual memory formation by selectively modulating the calcium-signaling pathways in the 
hippocampus, PFC, and amygdala. As shown in Figure 3 and Additional file 2: Figure S1a, nicotine significantly decreased the expression of IP3 receptor genes in the hippocampus and increased the expression of VDCC-mediated calcium signaling genes in the PFC and amygdala. Furthermore, we provide evidence for the nicotinic regulation of downstream protein kinase signaling pathways in the hippocampus, PFC, and amygdala of HIV-1Tg rats. Nicotine increased the expression of genes involved in MAPK and Creb signaling in the hippocampus and upregulated expression of CAMKs in the PFC and amygdala of HIV$1 \mathrm{Tg}$ rats (Table 2). These results indicate that nicotine shifted the formation of LTD into LTP induction in the hippocampus and promoted LTP expression in the PFC and amygdala, resulting in enhanced memory formation in HIV-1Tg rats. In contrast with our findings, Atluri and colleagues have demonstrated the negative effects of nicotine on the expression of synaptic plasticity gene expression and spine density in HIV-1 infected SK-N-MC cells [54]. Given the differences in the administration route of nicotine and different models of infection, an animal model of HIV-1 infection has more capability of assessing the mechanism of action of nicotine by providing detailed information in cognitively impaired HIV-1-infected patients. In fact, the observed positive effects of nicotine on the synaptic plasticity formation within the hippocampus, PFC, and amygdala circuits might be a secondary outcome caused by its anti-inflammatory effects in the central nervous system (CNS). Nicotine has been proved effective in suppressing inflammation in patients with Alzheimer and Parkinson diseases by modulating the cholinergic anti-inflammatory pathway, which contributes to cognitive enhancement in these patients. Recently, Depboylu et al. [19] reported that chronic inflammation induced by HIV-1 proteins reduced cholinergic transmission in the basal forebrain of rhesus macaques, suggested dysfunction of cholinergic anti-inflammatory pathway in the central nervous system. In this respect, the actions of nicotine in the anti-inflammatory system should be considered a factor in the findings from the present study that nicotine might also have an effect on microglia-dependent glutamate release, which could contribute to its modulatory effect in the neural circuits of learning and memory in HIV-1Tg rats.

\section{Nicotine shows differential effects on contextual memory formation in the health and disease states}

In addition to the effects of nicotine on synaptic plasticity formation in HIV-1Tg rats, we analyzed the effects of nicotine in F344 rats to determine whether the drug exerts differential modulator effects on the synaptic plasticity and memory formation in health and disease states. When F344 rats were subjected to chronic nicotine treatment, the drug had different effects on spatial working memory and contextual fear memory. The drug enhanced the working memory performance in the Ymaze, whereas it impaired the contextual fear memory in the passive avoidance test (Figs. 1 and 2). This observation is consistent with previous reports [55, 56], where chronic nicotine treatment impaired short- and longterm formation of contextual fear memory. Here, we also showed that nicotine modulated gene expression in the hippocampus, PFC, and amygdala that was different from the effects in HIV-1Tg rats. Further, chronic nicotine treatment increased the expression of genes in the intracellular calcium signaling, $\mathrm{Ca}^{+2} /$ calmodulindependent kinase, and IEG in the hippocampus and PFC, whereas it downregulated the majority of synaptic plasticity-related genes in the amygdala of F344 rats (Table 3). These results indicate that nicotine had positive effects on the hippocampus-PFC circuit-dependent spatial working memory but showed negative effects on the formation of long-term episodic memory by decreasing gene expression in the amygdala, which is a predominant neural component in the neural circuit of contextual fear memory formation.

\section{Conclusion}

The prevalence of cigarette smoking among HIV-1 infected patients is high. It has been hypothesized that patients with HIV-1 infection use nicotine to compensate for HIV-1-related complications, including cognitive deficit. Our results indicate that HIV-1 proteins significantly disrupt synaptic plasticity formation by altering the expression of genes involved in intracellular calcium signaling pathways in a brain region-specific manner, which results in the deficit in spatial and contextual fear memory observed in HIV-1Tg rats. On the other hand, the effect of HIV-1 proteins is attenuated by chronic nicotine treatment in HIV-1Tg rats. Interestingly, the effect of nicotine on spatial and contextual memory performance appears to be different in the healthy and disease states. This may explain why nicotine shows different effects on the stimulation of neural circuits of learning and memory in these two states. Together, these results are helpful for elucidating the molecular mechanisms underlying the cognitive impairment in HIV-1-infected smokers.

\section{Additional files}

Additional file 1: Table S1. List of primer sequences used in the study. Description and primer sequences of 80 candidate genes tested as potential synaptic plasticity formation genes in qRT-PCR array.

Additional file 2: Regulation of synaptic plasticity gene expression by nicotine in the PFC of HIV-1Tg (A) and F344 (B) rats.

Competing interest

The authors declare that they have no competing interest regarding this report. 


\section{Authors' contribution}

TN carried out the behavioral and molecular studies, performed the statistical analysis, and drafted the manuscript. JC and ZY helped to carry out the behavioral and molecular studies. SLC helped to conceive the study and draft the manuscript, and provided some agents and animals to the study. MDL conceived of the study, and participated in its design and coordination and helped to draft the manuscript. All authors read and approved the final manuscript.

\section{Acknowledgements}

The authors thank Drs. Guohua Song and Shaolin Wang for their assistance with sample collection during the experiments. This work was supported, in part, by US National Institutes of Health grants DA-016149 to SLC and DA-026356 to SLC and MDL.

\section{Author details}

'Department of Psychiatry and Neurobehavioral Sciences, University of Virginia, 450 Ray C Hunt Drive, Suite G-170, Charlottesville, VA 22903, USA ${ }^{2}$ Institute of Neurolmmune Pharmacology, Seton Hall University, South Orange, NJ, USA. ${ }^{3}$ Department of Biological Sciences, Seton Hall University, South Orange, NJ, USA

\section{Received: 27 May 2015 Accepted: 14 July 2015}

Published online: 24 July 2015

\section{References}

1. Kaul M, Lipton SA. Mechanisms of neuronal injury and death in HIV-1 associated dementia. Curr HIV Res. 2006;4(3):307-18.

2. Kaul M, Zheng J, Okamoto S, Gendelman HE, Lipton SA. HIV-1 infection and AIDS: consequences for the central nervous system. Cell Death Differ. 2005;12 Suppl 1:878-92.

3. Woods SP, Iudicello JE, Moran LM, Carey CL, Dawson MS, Grant I. HIV-associated prospective memory impairment increases risk of dependence in everyday functioning. Neuropsychology. 2008;22(1):110-7.

4. Morgan EE, Woods SP, Weber E, Dawson MS, Carey CL, Moran LM, et al. HIV-associated episodic memory impairment: evidence of a possible differential deficit in source memory for complex visual stimuli. $J$ Neuropsychiatry Clin Neurosci. 2009;21(2):189-98.

5. Fama R, Rosenbloom MJ, Nichols BN, Pfefferbaum A, Sullivan EV. Working and episodic memory in HIV infection, alcoholism, and their comorbidity: baseline and 1-year follow-up examinations. Alcohol Clin Exp Res. 2009;33(10):1815-24

6. Nahvi S, Cooperman NA. Review: the need for smoking cessation among HIV-positive smokers. AIDS Educ Prev. 2009;21(3 Suppl):14-27.

7. Reynolds NR. Cigarette smoking and HIV: more evidence for action. AIDS Educ Prev. 2009;21(3 Suppl):106-21.

8. Wojna V, Robles L, Skolasky RL, Mayo R, Selnes O, de la Torre T, et al, Associations of cigarette smoking with viral immune and cognitive function in human immunodeficiency virus-seropositive women. J Neurovirol. 2007:13(6):561-8

9. Cao JR, Wang SL, Wang J, Cui WY, Nesil T, Vigorito M, et al. RNA Deep Sequencing Analysis Reveals That Nicotine Restores Impaired Gene Expression by Viral Proteins in the Brains of HIV-1 Transgenic Rats. PLoS One. 2013:8(7):e68517.

10. Mayford M, Siegelbaum SA, Kandel ER. Synapses and memory storage. Cold Spring Harb Perspect Biol. 2012:4(6). doi: 10.1101/cshperspect.a005751.

11. Li WC, Soffe SR, Roberts A. Glutamate and acetylcholine corelease at developing synapses. Proc Natl Acad Sci U S A. 2004;101(43):15488-93.

12. Jerusalinsky D, Kornisiuk E, Izquierdo I. Cholinergic neurotransmission and synaptic plasticity concerning memory processing. Neurochem Res. 1997:22(4):507-15

13. Neri E, Musante V, Pittaluga A. Effects of the HIV-1 viral protein TAT on central neurotransmission: role of group I metabotropic glutamate receptors. Int Rev Neurobiol. 2007:82:339-56

14. Farr SA, Banks WA, Uezu K, Freed EO, Kumar VB, Morley JE. Mechanisms of HIV type 1-induced cognitive impairment: evidence for hippocampal cholinergic involvement with overstimulation of the VIPergic system by the viral coat protein core. AIDS Res Hum Retroviruses. 2002;18(16):1189-95.

15. Bracci $L$, Lozzi $L$, Rustici M, Neri P. Binding of HIV-1 gp120 to the nicotinic receptor. FEBS Lett. 1992;311(2):115-8.
16. Potter MC, Figuera-Losada M, Rojas C, Slusher BS. Targeting the Glutamatergic System for the Treatment of HIV-Associated Neurocognitive Disorders. J Neuroimmune Pharmacol. 2013;8(3):594-607.

17. Haughey NJ, Nath A, Mattson MP, Slevin JT, Geiger JD. HIV-1 Tat through phosphorylation of NMDA receptors potentiates glutamate excitotoxicity. J Neurochem. 2001;78(3):457-67.

18. Cheng J, Nath A, Knudsen B, Hochman S, Geiger JD, Ma M, et al. Neuronal excitatory properties of human immunodeficiency virus type 1 Tat protein. Neuroscience. 1998;82(1):97-106.

19. Depboylu C, Weihe E, Eiden LE. Lentiviral infection of rhesus macaques causes long-term injury to cortical and hippocampal projections of prostaglandin-expressing cholinergic basal forebrain neurons. J Neuropathol Exp Neurol. 2012;71(1):15-27.

20. Aigner TG. Pharmacology of memory: cholinergic-glutamatergic interactions. Curr Opin Neurobiol. 1995:5(2):155-60.

21. Sultana R, Ameno K, Jamal M, Miki T, Tanaka N, Ono J, et al. Low-dose nicotine facilitates spatial memory in ApoE-knockout mice in the radial arm maze. Neurol Sci. 2013;34(6):891-7.

22. Hernandez CM, Terry AV. Repeated nicotine exposure in rats: Effects on memory function, cholinergic markers and nerve growth factor. Neuroscience. 2005;130(4):997-1012

23. Dajas-Bailador FA, Lima PA, Wonnacott S. The alpha 7 nicotinic acetylcholine receptor subtype mediates nicotine protection against NMDA excitotoxicity in primary hippocampal cultures through a $\mathrm{Ca} 2+$ dependent mechanism. Neuropharmacology. 2000;39(13):2799-807.

24. Stevens TR, Krueger SR, Fitzsimonds RM, Picciotto MR. Neuroprotection by nicotine in mouse primary cortical cultures involves activation of calcineurin and L-type calcium channel inactivation. J Neurosci. 2003:23(31):10093-9.

25. O'Neill MJ, Murray TK, Lakics V, Visanji NP, Duty S. The role of neuronal nicotinic acetylcholine receptors in acute and chronic neurodegeneration. Curr Drug Targets CNS Neurol Disord. 2002;1(4):399-411.

26. Liu Q, Zhao B. Nicotine attenuates beta-amyloid peptide-induced neurotoxicity, free radical and calcium accumulation in hippocampal neuronal cultures. Br J Pharmacol. 2004:141(4):746-54.

27. Maurice T, Roman FJ, Su TP, Privat A. Beneficial effects of sigma agonists on the age-related learning impairment in the senescence-accelerated mouse (SAM). Brain Res. 1996;733(2):219-30.

28. Hughes RN. The value of spontaneous alternation behavior $(S A B)$ as a test of retention in pharmacological investigations of memory. Neurosci Biobehav Rev. 2004;28(5):497-505.

29. Paxinos G, Watson C. The Rat Brain in Stereotaxic Coordinates, 4th ed. New York: Academic; 1998.

30. Cui WY, Zhao S, Polanowska-Grabowska R, Wang J, Wei J, Dash B, et al. Identification and characterization of poly(l:C)-induced molecular responses attenuated by nicotine in mouse macrophages. Mol Pharmacol. 2013;83(1):61-72

31. Winer J, Jung CK, Shackel I, Williams PM. Development and validation of real-time quantitative reverse transcriptase-polymerase chain reaction fo monitoring gene expression in cardiac myocytes in vitro. Anal Biochem. 1999;270(1):41-9.

32. Reid W, Sadowska M, Denaro F, Rao S, Foulke J, Hayes N, et al. An HIV-1 transgenic rat that develops HIV-related pathology and immunologic dysfunction. Proc Natl Acad Sci U S A. 2001;98(16):9271-6.

33. Lashomb AL, Vigorito M, Chang SL. Further characterization of the spatial learning deficit in the human immunodeficiency virus-1 transgenic rat. J Neurovirol. 2009:15(1):14-24.

34. Vigorito M, LaShomb AL, Chang SL. Spatial learning and memory in HIV-1 transgenic rats. J Neuroimmune Pharmacol. 2007;2(4):319-28.

35. Chami M, Oules B, Paterlini-Brechot P. Cytobiological consequences of calcium-signaling alterations induced by human viral proteins. Biochim Biophys Acta. 2006;1763(11):1344-62.

36. Erdmann NB, Whitney NP, Zheng J. Potentiation of Excitotoxicity in HIVAssociated Dementia and the Significance of Glutaminase. Clin Neurosci Res. 2006:6(5):315-28.

37. Marambaud $P$, Dreses-Werringloer $U$, Vingtdeux V. Calcium signaling in neurodegeneration. Mol Neurodegener. 2009:4:20.

38. Legendre P, Rosenmund C, Westbrook GL. Inactivation of NMDA channels in cultured hippocampal neurons by intracellular calcium. J Neurosci. 1993;13(2):674-84 
39. Rosenmund C, Westbrook GL. Rundown of N-methyl-D-aspartate channels during whole-cell recording in rat hippocampal neurons: role of $\mathrm{Ca} 2+$ and ATP. J Physiol. 1993;470:705-29.

40. Rycroft BK, Gibb AJ. Direct effects of calmodulin on NMDA receptor single-channel gating in rat hippocampal granule cells. J Neurosci. 2002;22(20):8860-8.

41. Byrnes KR, Loane DJ, Stoica BA, Zhang J, Faden Al. Delayed mGluR5 activation limits neuroinflammation and neurodegeneration after traumatic brain injury. J Neuroinflammation. 2012;9:43.

42. Palmer E, Monaghan DT, Cotman CW. Glutamate receptors and phosphoinositide metabolism: stimulation via quisqualate receptors is inhibited by N-methyl-D-aspartate receptor activation. Brain Res. 1988:464(2):161-5

43. Naie K, Tsanov M, Manahan-Vaughan D. Group I metabotropic glutamate receptors enable two distinct forms of long-term depression in the rat dentate gyrus in vivo. Eur J Neurosci. 2007;25(11):3264-75.

44. Mattson MP, LaFerla FM, Chan SL, Leissring MA, Shepel PN, Geiger JD. Calcium signaling in the ER: its role in neuronal plasticity and neurodegenerative disorders. Trends Neurosci. 2000;23(5):222-9.

45. Vicencio JM, Lavandero S, Szabadkai G. Ca2+, autophagy and protein degradation: Thrown off balance in neurodegenerative disease. Cell Calcium. 2010:47(2):112-21.

46. Maroun M, Richter-Levin G. Exposure to acute stress blocks the induction of long-term potentiation of the amygdala-prefrontal cortex pathway in vivo. J Neurosci. 2003;23(11):4406-9.

47. Kim JJ, Lee HJ, Han JS, Packard MG. Amygdala is critical for stress-induced modulation of hippocampal long-term potentiation and learning. J Neurosci. 2001:21(14):5222-8.

48. Kim JJ, Diamond DM. The stressed hippocampus, synaptic plasticity and lost memories. Nat Rev Neurosci. 2002;3(6):453-62.

49. Levin ED, McClernon FJ, Rezvani AH. Nicotinic effects on cognitive function: behavioral characterization, pharmacological specification, and anatomic localization. Psychopharmacology (Berl). 2006;184(3-4):523-39.

50. Rezvani AH, Levin ED. Cognitive effects of nicotine. Biol Psychiatry. 2001:49(3):258-67.

51. Akaike A, Takada-Takatori Y, Kume T, Izumi Y. Mechanisms of neuroprotective effects of nicotine and acetylcholinesterase inhibitors: role of alpha4 and alpha7 receptors in neuroprotection. J Mol Neurosci. 2010;40(1-2):211-6.

52. Shen JX, Yakel JL. Nicotinic acetylcholine receptor-mediated calcium signaling in the nervous system. Acta Pharmacol Sin. 2009;30(6):673-80.

53. Shen $H$, Kihara $T$, Hongo $H$, Wu X, Kem WR, Shimohama S, et al. Neuroprotection by donepezil against glutamate excitotoxicity involves stimulation of alpha7 nicotinic receptors and internalization of NMDA receptors. Br J Pharmacol. 2010;161(1):127-39.

54. Atluri VS, Pilakka-Kanthikeel S, Samikkannu T, Sagar V, Kurapati KR, Saxena SK, et al. Vorinostat positively regulates synaptic plasticity genes expression and spine density in HIV infected neurons: role of nicotine in progression of HIV-associated neurocognitive disorder. Mol Brain. 2014;7:37

55. Kenney JW, Gould TJ. Nicotine Enhances Context Learning but Not Context-Shock Associative Learning. Behav Neurosci. 2008;122(5):1158-65.

56. Davis JA, James JR, Siegel SJ, Gould TJ. Withdrawal from chronic nicotine administration impairs contextual fear conditioning in C57BL/6 mice. J Neurosci. 2005;25(38):8708-13.

\section{Submit your next manuscript to BioMed Central and take full advantage of:}

- Convenient online submission

- Thorough peer review

- No space constraints or color figure charges

- Immediate publication on acceptance

- Inclusion in PubMed, CAS, Scopus and Google Scholar

- Research which is freely available for redistribution 